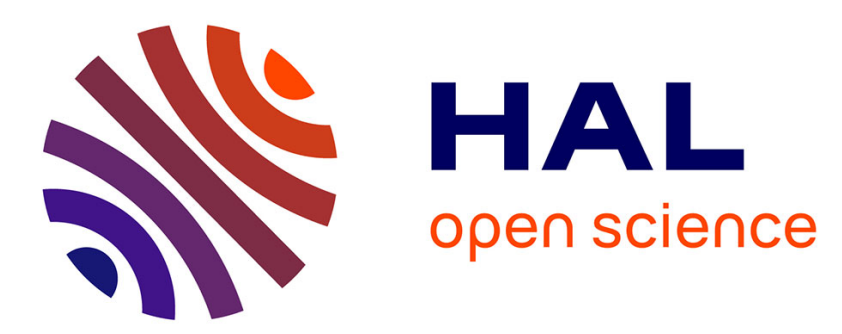

\title{
Radiation chemistry of the branched-chain monoamide di-ethylhexyl-isobutyramide
}

J. Drader, G. Saint Louis, J.M. Muller, M.-C. Charbonnel, P. Guilbaud, L. Berthon, K.M. Roscioli-Johnson, C. Zarzana, C. Rae, G.S. Groenewold, et al.

\section{- To cite this version:}

J. Drader, G. Saint Louis, J.M. Muller, M.-C. Charbonnel, P. Guilbaud, et al.. Radiation chemistry of the branched-chain monoamide di-ethylhexyl-isobutyramide. Solvent Extraction and Ion Exchange, 2017, 35, pp.480-495. 10.1080/07366299.2017.1379713 . cea-02418704

\section{HAL Id: cea-02418704 https://hal-cea.archives-ouvertes.fr/cea-02418704}

Submitted on 19 Dec 2019

HAL is a multi-disciplinary open access archive for the deposit and dissemination of scientific research documents, whether they are published or not. The documents may come from teaching and research institutions in France or abroad, or from public or private research centers.
L'archive ouverte pluridisciplinaire $\mathbf{H A L}$, est destinée au dépôt et à la diffusion de documents scientifiques de niveau recherche, publiés ou non, émanant des établissements d'enseignement et de recherche français ou étrangers, des laboratoires publics ou privés. 


\title{
Radiation chemistry of the branched-chain monoamide di-ethylhexyl- isobutyramide
}

\author{
J. Drader, G. Saint-Louis, J.M. Muller, M-C. Charbonnel, P. Guilbaud, L. Berthon \\ CEA Marcoule, Bagnols-sur-Cèze Cedex, F-30207, France \\ K. M. Roscioli-Johnson, C. A. Zarzana, C. Rae, G. S. Groenewold, B. J. Mincher \\ Idaho National Laboratory, Idaho Falls ID, 83415, USA \\ S.P. Mezyk \\ California State University, Long Beach, Long Beach, CA, 90840, USA \\ K. McCann, S. G. Boyes, J. Braley \\ Colorado School of Mines, Golden, CO, 80401, USA
}

\begin{abstract}
The radiolytic degradation of di-ethylhexyl-isobutyramide (DEH $i \mathrm{BA}$ ) was examined by subjecting the compound to gamma irradiation, measuring the remaining concentration of the intact compound, identifying the degradation products and measuring uranium distribution ratios. The combined effects of radiation dose, contact with aqueous solutions of $\mathrm{HNO}_{3}$, and aeration were also examined. The DEHiBA displayed significant stability at doses up to $1000 \mathrm{kGy}$, undergoing a slow exponential concentration decrease that was accompanied by the appearance of multiple degradation products. The most abundant compounds that were formed by radiolysis resulted from cleavage of the $\mathrm{C}_{\text {carbonyl }}-\mathrm{N}$ and $\mathrm{C}_{\text {ethylhexyl }} \mathrm{N}$ bonds, generating di-ethylhexylamine, and mono- ethylhexyl-isobutyramide. Acid contact did alter the radiolytic pathways, with acid favoring cleavage of the $\mathrm{C}_{\text {carbonyl }}-\mathrm{N}$ bond, while a more diverse array of compounds were formed in the absence of acid. Pulsed radiolysis experiments were also conducted, in which picosecond bursts of energetic electrons were used to irradiate solutions of dodecane containing DEH $i \mathrm{BA}$; formation of the dodecane radical cation was implicated, which serially reacted with DEH $i \mathrm{BA}$ to form radical or radical cation species intermediate in the formation of the observed products. The
\end{abstract}


slow degradation kinetics suggests that $\mathrm{DEH} i \mathrm{BA}$ possesses good potential for selective extraction of uranium in fuel cycle extraction operations.

\section{INTRODUCTION}

The dialkyl-monoamide class of extactant molecules has been studied for several decades as alternatives to tributylphosphate (TBP) in PUREX-type separations for the nuclear fuel cycle. Their advantages over TBP, as summarized in a review by Gasparini and Grossi, ${ }^{[1]}$ include greater selectivity for uranium over fission products, higher radiolytic stability, generation of inoffensive radiolysis products, and the elimination of phosphorous. This latter point is referred to as adherence to the $\mathrm{CHON}$ principle, in which reagents are composed of only carbon, hydrogen, oxygen and nitrogen, making them incinerable and thus preferable to phosphorouscontaining ligands for used nuclear fuel treatment purposes.

An additional advantage of the dialkyl-monoamides over TBP is the ease of their synthetic tunability. This feature allows for metal ion selectivity to be designed into the structure of the monoamide. For example, although $n$-alkane substituted monoamides have overall higher extraction efficiencies for U(VI), branched-chain alkane-substituted monoamides are used for selection of $\mathrm{U}(\mathrm{VI})$ over $\mathrm{Th}(\mathrm{IV})$ and $\mathrm{Pu}(\mathrm{IV})$. Branching at the $\alpha$-carbon of the alkane attached to the carbonyl carbon was shown to increase the separation factor for uranium from the tetravalent ions including zirconium, ${ }^{[2]}$ and to minimize third phase formation due to an overall lower concentration of metal in the organic phase. ${ }^{[3]}$ Prabhu et al. reported that di-2-ethylhexylbutyramide (DEHBA, Figure 1) extracts $\mathrm{U}(\mathrm{VI})$ and $\mathrm{Pu}(\mathrm{IV})$, while di-2-ethylhexyl-isobutyramide (DEHiBA) selectively extracts $\mathrm{U}(\mathrm{VI})$, although with a lower $D_{\mathrm{U}}$ than for the unbranched

monoamide. ${ }^{[4]}$ Thus, for U/Pu co-extraction, DEHBA is preferred, while for applications involving selective extraction of $\mathrm{U}, \mathrm{DEH} i \mathrm{BA}$ is a better extractant. In the Gasparini and Grossi 
review, ${ }^{[1]}$ the stability of monoamides toward $\gamma$-radiolysis was reported to be relatively unaffected by the nature of the alkane groups, though Mowafy ${ }^{[5]}$ reported that unsymmetrically substituted monoamides were more susceptible to radiolytic damage.

Although it has been commonly claimed that the monoamides have good radiation stability, there are few literature reports quantitatively investigating this. They involve mainly postirradiation studies of effects on solvent extraction and attempts to identify degradation products by spectroscopic or GC methods. ${ }^{[5-13]}$ The major products are invariably reported to be the corresponding amine and organic acid, suggesting rupture of the carbonyl C-N bond. For example, Musikas ${ }^{[14,15]}$ reported that the products of di-2-ethylhexyl-hexanamide radiolysis were di-2-ethylhexyl-amine and hexanoic acid. However, the secondary amine was produced in substoichiometric amounts, suggesting that it hydrolyzed in the presence of acid. Similarly, Parikh et al. ${ }^{[8]}$ identified the main products of $d i$-hexyl-octanamide radiolysis using GC/GC-MS as $d i$ hexyl-amine and octanoic acid. Uranium and plutonium extraction and subsequent stripping were little affected by an absorbed dose of $600 \mathrm{kGy}$. This was attributed to the innocuous, watersoluble nature of the monoamide degradation products which is in stark contrast to the degradation products of tributylphosphate $(\mathrm{TBP})^{[13,16]}$, highlighting one of their advantages over the conventional extractant. Similarly, di-2-ethylhexyl-amine and isobutanoic acid were reported by Pathak et al. as the products of DEHiBA irradiation in the presence of $3-4 \mathrm{M} \mathrm{HNO}_{3}$, and the ability to strip the loaded solvent of uranium and plutonium was maintained even at $600 \mathrm{kGy}$ absorbed dose. ${ }^{[9]}$

As the monoamides continue to be developed for potential application to the nuclear fuel cycle, research has been focused on the behavior of DEHBA and DEHiBA, (Figure 1). The goal of this work is to provide a rigorous examination of the radiolytic decomposition of the uranium selective DEHiBA by identifying its degradation dose constants and products using mass 
spectrometry and measuring the impact on the extraction behavior of uranium(VI) by the irradiated solvent.

\section{EXPERIMENTAL}

\section{Materials}

The DEHiBA used in the preliminary work was prepared at Colorado School of Mines (USA) using a 1.2:1 molar ratio of iso-butyryl chloride diluted in chloroform, added dropwise to a mixture of the secondary amine, bis-2-ethylhexyl-amine, diluted in chloroform and tri-ethylamine. The dropwise addition was done in a nitrogen atmosphere at $5{ }^{\circ} \mathrm{C}$ under vigorous stirring. Once mixed, the solution was refluxed for 2 hours at $60{ }^{\circ} \mathrm{C}$. This solution was then filtered and washed with water, $10 \mathrm{wt} \%$ sodium carbonate, and $1 \mathrm{M} \mathrm{HCl}$ to remove unreacted tri-ethyl-amine as well as residual iso-butyryl chloride. The solution was then dried with sodium sulfate overnight. To purify the product, chloroform was removed by rotary evaporation followed by vacuum distillation. Characterization by ${ }^{1} \mathrm{H}-\mathrm{NMR}$ showed the product to be $99 \%+$ pure. Upon the need for larger volumes for irradiations and solvent extraction, DEHiBA was purchased from Technocom (UK).

\section{Steady State Irradiations}

A $1 \mathrm{M}$ solution of the monoamide was prepared by combining the appropriate amount of weighed DEHiBA in dodecane for irradiation. Samples were irradiated using a ${ }^{60}$ Co Nordion Gammacell 220, at a dose rate that varied from $4.73-4.34 \mathrm{kGy} \cdot \mathrm{h}^{-1}$ during the course of the experiments. This dose rate was initially measured using standard Fricke procedures ${ }^{[17]}$, and then subsequently corrected for ${ }^{60} \mathrm{Co}$ decay. The sample chamber temperature was approximately 30 ${ }^{\circ} \mathrm{C}$. The solutions were irradiated either as dry organic solutions, or in contact with either $0.1 \mathrm{M}$ 
$\mathrm{HNO}_{3}$ (stripping acidity), or $4 \mathrm{M} \mathrm{HNO}_{3}$ (extraction acidity). In some cases, the samples were irradiated in static, sealed containers, considered deaerated upon exposure to even low absorbed doses. Some samples, as indicated in the text, were irradiated with air sparging at a rate of 1 $\mathrm{mL} \cdot \mathrm{min}^{-1}$, as delivered from a compressed air bottle through a mass flow controller. This was done to ensure that the samples so treated remained saturated with dissolved oxygen. Following irradiation, the samples were split for analysis by the collaborating laboratories at CEA-Marcoule and INL. Organic-only samples were irradiated to 500, 750, and $1000 \mathrm{kGy}$, while the $0.1 \mathrm{M}$ and 4.0 $\mathrm{M} \mathrm{HNO}_{3}$-contacted samples were irradiated to 500, 750, 1000, and $1250 \mathrm{kGy}$.

\section{Pulsed Irradiations}

Picosecond electron pulse radiolysis/transient absorption experiments were performed at the Brookhaven LEAF facility, as described previously. ${ }^{[18]}$ Samples were irradiated in $1.00-\mathrm{cm}$ Suprasil semimicro cuvettes sealed with Teflon stoppers. The doses per pulse for various experiments were in the range 20-40 Gy. Time-resolved kinetics were obtained using a FND-100 silicon diode detector and digitized using a LeCroy WaveRunner 640Zi oscilloscope (4 GHz, 8 bit). Interference filters $(* 10-n m$ bandpass $)$ were used for the wavelength selection of the analyzing light.

\section{Analytical Measurements}

\section{Electrospray ionization-Mass Spectrometry (ESI-MS) analysis}

The mass spectrometry measurements were recorded in positive ion mode using a Bruker Esquire-LC quadrupole ion trap equipped with an electrospray interface. A Cole Palmer syringe infusion pump delivered the sample at a rate of $90 \mu \mathrm{L} \cdot \mathrm{h}^{-1}$ to the electrospray source. The capillary voltage was set to $-4000 \mathrm{~V}$. Nitrogen was employed as the drying and nebulizing gas. The drying 
gas flow rate was $5.0 \mathrm{~L} \mathrm{~min}^{-1}$ and the nebulizing gas pressure was set to 5.0 psi. The source temperature was $250{ }^{\circ} \mathrm{C}$. Spectra were acquired over a mass/charge $(\mathrm{m} / z)$ range of $45-2200$ with a trap drive setting of 50.0 at various skimmer voltages. Helium gas was used as the buffer gas in the trap to improve trapping efficiency and as a collision gas for fragmentation experiments.

Each sample was prepared by dilution in acetonitrile to a concentration of $1.0 \times 10^{-4} \mathrm{M}$. To favor the ionization of compounds and avoid the formation of sodiated adducts, samples irradiated without an aqueous phase were acidified before analysis by addition of 1 drop of $1 \mathrm{M}$ nitric acid. The ESI-MS measurements were taken within a short time after sample preparation to avoid any solvent influences on the speciation of degradation products. Species were identified by comparison with an isotopic pattern calculated using the software DataAnalysis 4.0. Ion trap collision induced dissociation (CID) experiments were used to help identify the structures of various species through fragmentation studies.

\section{$\underline{\text { UHPLC-ESI-MS analysis }}$}

Aliquots of the same samples were also analyzed at INL in positive ion mode, using a Dionex (Thermo Fisher, Sunnyvale, CA) Ultimate 3000 UHPLC coupled to a Bruker (Billerica, MA) micrOTOF-Q II electrospray ionization mass spectrometer (UHPLC-ESI-MS). The UHPLC-ESIMS was used to identify the degradation products in all samples and also to quantify the DEHiBA concentrations in the two organic-only samples. The mass spectrometer nitrogen drying gas flow rate was $9 \mathrm{~mL} \cdot \mathrm{min}^{-1}$, with a nebulizer gas pressure of 5.8 psi. The mass spectrometer conditions were a capillary voltage of $-4000 \mathrm{~V}$ and a source temperature of $220{ }^{\circ} \mathrm{C}$. All solvents used for sample dilution and mobile phases were Thermo Fisher Scientific (Waltham, MA USA) Optima ${ }^{\circledR}$ LC-MS grade. Samples were diluted by a factor of $10^{3}$ in 2propanol followed by a factor of $4 \times 10^{2}$ in $50 \% 150 \%$ acetonitrile/water prior to analysis. The LC eluent was isocratic with $65 \%$ acetonitrile $/ 35 \% 0.1 \%$ formic acid in water at a flow rate of 
$400 \mu \mathrm{L} \cdot \mathrm{min}^{-1}$. Separations were achieved using $5 \mu \mathrm{L}$ injections through a flow-through needle onto a Kinetex $1.3 \mu \mathrm{m}$ particle C18 $50 \mathrm{~mm} \times 2.1 \mathrm{~mm}$ column (Phenomenex, Torrance, CA, USA). Each sample was analyzed in quintuplicate. DEH $i$ BA was quantified using a calibration curve spanning the equivalent (accounting for dilution) of $2 \mathrm{M}$ to $0.1 \mathrm{M}$ DEHiBA. No standards were available for the degradation products, so their response is the integrated LC-MS peak area. $\underline{G C-F I D \text { and GC-MS analysis }}$

Samples of DEHiBA contacted with 0.1 $\mathrm{M}$ and 4.0 $\mathrm{M} \mathrm{HNO}_{3}$, de-aerated and aerated, were analyzed using an Agilent (Santa Clara, CA, USA) 7890 gas chromatograph with Flame Ionization Detection (GC-FID) and an Agilent 7890A gas chromatograph with a 5975C MSD electron-impact quadrupole mass spectrometer (GC-EI-MS). Samples were diluted into the $\mathrm{mM}$ concentration range in Thermo Fisher Scientific (Waltham, MA USA) Optima ${ }^{\circledR}$ LC-MS 2propanol. Each sample was analyzed in triplicate. Both systems used a Restek (Bellefonte, PA, USA) Rtx-5 $\left(30 \mathrm{~m} \times 0.32 \mathrm{~mm}\right.$ ID $\left.\times 0.25 \mu \mathrm{m} \mathrm{d}_{\mathrm{f}}\right)$. For the GC-FID analysis, the injector and detector were held at $300{ }^{\circ} \mathrm{C}$ throughout the run. The oven was held at $100{ }^{\circ} \mathrm{C}$ for 1 minute, followed by a ramp at $15^{\circ} \mathrm{C} / \mathrm{min}$ to 275 , and a final hold at $275^{\circ} \mathrm{C}$ for 1 minute. For the GC-EIMS analysis, the injector and ion source were held at $250{ }^{\circ} \mathrm{C}$, while the quadrupole was held at $200{ }^{\circ} \mathrm{C}$ for the duration of the run. The oven was held at $100{ }^{\circ} \mathrm{C}$ for 1 minute, followed by a ramp at $10{ }^{\circ} \mathrm{C} / \mathrm{min}$ to $300{ }^{\circ} \mathrm{C}$, with a final hold at $300{ }^{\circ} \mathrm{C}$ for 1 minute. Quantification of $\mathrm{DEH} i \mathrm{BA}$ by GC-FID and GC-EI-MS produced statistically indistinguishable results, though the uncertainties for GC-FID were lower than those for GC-EI-MS.

\section{$\underline{F T-I R \text { analysis }}$}

Organic phase samples were analyzed with a Bruker Vertex 70 spectrometer equipped with an attenuated total reflectance cell. All spectra were collected between $400-4000 \mathrm{~cm}^{-1}$, using 32 scans and a resolution of $4 \mathrm{~cm}^{-1}$. 


\section{Uranium (VI) Solvent Extraction}

Uranium solvent extraction distribution ratios, $D_{\mathrm{U}}$, were measured for both irradiated and nonirradiated solutions at INL. The aqueous phase contained $1 \times 10^{-5} \mathrm{M}$ natural uranium at the appropriate acidity. Preliminary experiments during this study showed that neither acid preequilibration of the organic phase, nor various contact times over the range of $30 \mathrm{sec}-10 \mathrm{~min}$ affected the $D_{\mathrm{U}}$ value. Subsequently the extractions reported here used non-pre-equilibrated, 30sec, equal volume contacts at $23 \pm 2{ }^{\circ} \mathrm{C}$. Although $4 \mathrm{M} \mathrm{HNO}_{3}$ is proposed for process application extractions, the maximum $D_{\mathrm{U}}$ value here was obtained at an initial aqueous phase acidity of 6.5 M $\mathrm{HNO}_{3}$. Therefore all $D_{\mathrm{U}}$ values to examine irradiation effects were measured at this initial acidity. Stripping was performed using $0.1 \mathrm{M} \mathrm{HNO}_{3}$ with 1-min contacts. These concentrations were determined by mass spectrometry using a Thermo X series 2 ICP-MS with a Teflon sample introduction system and platinum cones. During analysis of organic solutions, $0.2 \mathrm{~L} \cdot \mathrm{min}^{-1}$ of 20 $\%$ oxygen in argon was added to the spray chamber to aid in combustion of the organic material and to reduce build up on the cones. Organic solutions were emulsified with Triton TX100 into the normal $1 \%$ nitric acid solution used to dilute samples prior to analysis. Mass balances were calculated by comparison to the initial aqueous feed uranium concentration and averaged $98 \pm 6$ $\%$.

\section{RESULTS AND DISCUSSION}

\section{Degradation rates for monoamide radiolysis}

The radiolytic decay kinetics of DEH $i \mathrm{BA}$ can be determined by monitoring the concentration of the monoamide in organic solution as a function of absorbed dose. The concentration of $\mathrm{DEH} i \mathrm{BA}$ decreased slowly as absorbed dose increased, as seen in Figure 2. The rate was slow 
and approximately $70 \%$ of the initial monoamide concentration remained intact even at an absorbed dose of $1250 \mathrm{kGy}$, under all conditions of acidity and aeration. The exponential nature of the decay suggests pseudo-first order kinetics, so a dose constant is the appropriate description of the radiolytic decay process.

Linear regression analysis of plots of the natural log of measured concentration versus absorbed dose was used to determine the dose constants $(d)$ for monoamide degradation as the exponential constants of each equation. These values ranged from $(2.0 \pm 1.0) \times 10^{-4} \mathrm{kGy}^{-1}$ for the 4.0 $\mathrm{M} \mathrm{HNO}_{3}$-contacted organic phase to $(3.5 \pm 1.4) \times 10^{-4} \mathrm{kGy}^{-1}$ for the de-aerated organic-only samples. The larger uncertainties in the two organic-only samples are due to the larger measurement uncertainties from the UHPLC-ESI-MS measurements.

A comparison of the dose constants ( $d$ values, Table 1$)$ shows that rates of DEH $i \mathrm{BA}$ radiolysis in the organic phase were unaffected by aeration, or by contact with aqueous $\mathrm{HNO}_{3}$ (either 0.1 or 4.0 M). This suggests that all conditions had roughly the same degradation kinetics, and the range is attributable to the difficulties inherent in measuring the small concentration change that occurred across these absorbed doses. The mean value for all conditions for both trials in Table 1 is $(3.0 \pm 0.9) \times 10^{-4} \mathrm{kGy}^{-1}$. These results are similar to those previously reported for diglycolamides, ${ }^{[18-20]}$ where the aqueous phase and aeration had little or no effect on degradation rates. However, the rate of monoamide degradation is about a factor of 10 slower than for the diglycolamides. ${ }^{[18,19]}$ The stability measured here seems to be of the same order of magnitude as that found for malonamides in alkane irradiated after contact with an aqueous phase of water or 1-4 M nitric acid. ${ }^{[21]}$ In that study, approximately $70-80 \%$ of the initial concentration of three different malonamides remained after an absorbed dose of $750 \mathrm{kGy}\left(-G_{\text {malonamides }}=0.52-0.55\right.$ $\mu \mathrm{mol} \cdot \mathrm{J}^{-1}$ in presence of $4 \mathrm{M}$ nitric acid). It has been hypothesized that for the DGAs, the ether 
linkage is the most radiolytically vulnerable bond in the molecule. As the monoamides do not have an ether bond, the observation that their radiolytic degradation rates are significantly lower than those for the DGAs is consistent with this hypothesis.

In spite of the large body of literature examining TBP radiolysis, few $G$-values have been reported for irradiation under conditions of contact with the acidic aqueous phase, and typically the yield of the main decomposition product dibutylphosphoric acid (HDBP) is reported instead of the actual decrease in TBP concentration. These $G_{\mathrm{HDBP}}$ values fall in the range of $0.05-0.5$ $\mu \mathrm{mol} \cdot \mathrm{J}^{-1}$ for alkane solutions in the absence of the aqueous phase,${ }^{[16]}$ but obviously underestimate the actual $-G_{\mathrm{TBP}}$. Adamov reported $-G_{\mathrm{TBP}}=0.37 \mu \mathrm{mol} \cdot \mathrm{J}^{-1}$ in the presence of acid. ${ }^{[22]}$ If the mean dose constant reported here of $3.0 \times 10^{-4} \mathrm{kGy}^{-1}$ (for all six experiments) is used to calculate a $G$ value $^{[18]}$ for the radiolytic degradation of initially $1 \mathrm{M}$ DEH $i \mathrm{BA}$, a value of $-G_{\mathrm{DEH} i \mathrm{BA}}=0.53$ $\mu \mathrm{mol} \cdot \mathrm{J}^{-1}$ is obtained, which is comparable to that of TBP.

\section{Radical cation reactions with DEHiBA}

The irradiation of non-acid contacted dodecane results in degradation of the diluent through molecular ionization to generate solvated electrons, $\left(\mathrm{e}_{\text {solv }}^{-}\right)$, radical cations $\left(\mathrm{C}_{12} \mathrm{H}_{26}{ }^{+\bullet}\right)$ and $\mathrm{C}-\mathrm{H} / \mathrm{C}-$ $\mathrm{C}$ bond breakage to generate neutral radicals $\left(\mathrm{C}_{\mathrm{x}} \mathrm{H}_{\mathrm{y}}{ }^{\bullet}, \mathrm{H}^{\bullet}\right)$. Under aerated conditions it would be expected that the carbon-centered radicals, hydrogen atoms and solvated electrons would react with dissolved oxygen to form a suite of less-reactive peroxyl $\left(\mathrm{C}_{\mathrm{x}} \mathrm{H}_{\mathrm{y}} \mathrm{O}_{2}{ }^{\bullet}\right)$ and superoxide $\left(\mathrm{HO}_{2}{ }^{\bullet} / \mathrm{O}_{2}^{-\bullet}\right)$ radicals. These conditions isolate the diluent radical cation $\left(\mathrm{C}_{12} \mathrm{H}_{26}{ }^{+\bullet}\right)$ as the major reactive species that causes $\mathrm{DEH} i \mathrm{BA}$ degradation in the organic phase.

Therefore, in this study, we elucidated the kinetics of this radical cation reaction with DEH $i \mathrm{BA}$ in dodecane. These fast, pulsed, electron radiolysis experiments were performed as detailed 
previously, ${ }^{[18]}$ using $0.50 \mathrm{M} \mathrm{CH}_{2} \mathrm{Cl}_{2}$ /aerated dodecane to isolate the radical cation with its absorbance directly monitored at $800 \mathrm{~nm}$. Typical kinetic data for the decay of this species in the presence of $\mathrm{DEH} i \mathrm{BA}$ are seen in Figure 3. As the amount of DEHiBA increases, the decay becomes faster, indicating the dodecane radical cation reacting is being consumed by $\mathrm{DEH} i \mathrm{BA}$. From the analysis of the shown decay curves the plot inset shown in Figure 3 is derived. The slope of this plot gives the second-order rate constant for the reaction of $\mathrm{C}_{12} \mathrm{H}_{26}{ }^{+\bullet}$ with DEHiBA as $k=(1.52 \pm 0.11) \times 10^{10} \mathrm{M}^{-1} \cdot \mathrm{s}^{-1}$ :

$\mathrm{C}_{12} \mathrm{H}_{26}{ }^{+\bullet}+\mathrm{DEH} i \mathrm{BA} \rightarrow \mathrm{C}_{12} \mathrm{H}_{26}+[\mathrm{DEH} i \mathrm{BA}]^{+\bullet}$

This effectively diffusion-controlled rate constant suggests that this reaction would be an important process in the overall organic phase degradation of this ligand, and supports the hypothesis that it may account for the appearance of the $\mathrm{m} / \mathrm{z} 310.2$ compound (which is a ligand formed by abstraction of two hydrogen atoms) when it occurs in the organic-only solution (vida infra).

\section{Organic phase analysis-FTIR}

To gain information about the nature of the degradation products formed under different experimental conditions, IR analyses were performed. Figure 4 and Figure 5 show a comparison of the sample spectrum before and after irradiation to $1000 \mathrm{kGy}$, for two conditions: without aqueous phase and with $4 \mathrm{M} \mathrm{HNO}_{3}$ present, respectively. Figure 4 compares the impact of irradiation alone to air-sparging during irradiation on monoamide degradation without an aqueous phase present. The solid line represents $1 \mathrm{M}$ DEHiBA dissolved in dodecane before irradiation. Upon irradiation, there appears to be little impact on the nature of the degradation products in the 
non-air-sparged sample. This could indicate that the degradation products generated by irradiation maintain similar functional groups as the parent monoamide and are thus not unambiguously observable by IR.

In the air-sparged sample, the spectra are slightly different. A shoulder appears at $1175 \mathrm{~cm}^{-1}$ which could represent a $\mathrm{C}-\mathrm{N}$ stretch in an aliphatic amine. A new peak is also observed at 1730 $\mathrm{cm}^{-1}$ as well as a shoulder peak at $1625 \mathrm{~cm}^{-1}$. The appearance of the peak at $1730 \mathrm{~cm}^{-1}$ might indicate formation of a carboxylic acid (a common degradation product previously reported for monoamides). Development of the shoulder peak at $1625 \mathrm{~cm}^{-1}$ could indicate formation of a new amide species by representing a shift in amide functionality. Other species that are commonly generated during monoamide degradation that would show $\mathrm{C}=\mathrm{O}$ stretches in this region include ketones and esters. Interestingly, based on this comparison, air-sparging of the sample during irradiation changes the nature of the degradation products formed compared to irradiation under anaerobic conditions.

When the sample is irradiated in the presence of acid, slightly different spectra are observed, (Figure 5). The solid line in Figure 5 represents $1 \mathrm{M}$ DEHiBA dissolved in dodecane contacted with $4 \mathrm{M} \mathrm{HNO}_{3}$. The spectrum of this sample shows a new $\mathrm{HNO}_{3}$-monoamide peak at $1587 \mathrm{~cm}^{-1}$ which has been assigned as the $\mathrm{C}=\mathrm{O}$ group bonded to $\mathrm{HNO}_{3}{ }^{[20,23,24]}$ Other new bands appear at $1284 \mathrm{~cm}^{-1}, 940 \mathrm{~cm}^{-1}, 827 \mathrm{~cm}^{-1}$, and $686 \mathrm{~cm}^{-1}$, all of which are consistent with the presence of nitric acid in the organic phase. After irradiation, in both the air-sparged and non-air-sparged samples, the same peaks appear as in the air-sparged sample of the organic-only irradiated sample: $1730 \mathrm{~cm}^{-1}$ and $1625 \mathrm{~cm}^{-1}$. These likely represent bands from the same or similar degradation products that were observed in the aerated, organic-only sample. Interestingly, there is a clear decrease in the absorbance of the bands representing the $\mathrm{C}=\mathrm{O}-\mathrm{HNO}_{3}$ stretch $\left(1587 \mathrm{~cm}^{-1}\right.$ 
and $827 \mathrm{~cm}^{-1}$ ) upon irradiation for both the air-sparged and non-air-sparged samples. This is consistent with a decrease of the nitric acid concentration in the organic phase after irradiation.

The conclusions from this analysis are that under both oxidizing conditions of acid and airsparging, similar degradation products are formed and these are slightly different than those that formed due to irradiation of the de-aerated organic phase alone. To identify these products, the samples were analyzed by mass spectrometry.

\section{Organic phase ESI-MS analysis}

Mass spectra of the irradiated and non-irradiated samples show both the protonated and sodiated parent monomer and dimer compounds at $\mathrm{m} / \mathrm{z}=312.2,334.2$ and $\mathrm{m} / \mathrm{z}=623.0,645.5$, respectively. Also observed in the spectra of irradiated and non-irradiated samples is a product at $m / z=242.2$ corresponding to bis-2-ethylhexyl-amine (DEHA), produced by carboxyl C-N bond rupture. It should be noted that though traces of DEHA were also found in non-irradiated samples, likely as an impurity from synthesis, it was also clearly generated during irradiation. Supplementary Information Table S1 includes a summary of all degradation products found with an indication of specific experimental conditions under which they were formed. Most products were detected regardless the experimental conditions, though the relative yields of the degradation products were affected by the experimental conditions.

In the low molecular weight region of the mass spectra of the irradiated solutions, several degradation products were detected (see Supplementary Information Table S1). The ESI-MS spectra for two of the aqueous phase conditions (no aqueous phase, $4 \mathrm{M} \mathrm{HNO}_{3}$ ) are shown in Figure 6. The $0.1 \mathrm{M} \mathrm{HNO}_{3}$ sample spectra were not shown because they only give intermediate results between the no aqueous phase and $4 \mathrm{M} \mathrm{HNO}_{3}$ conditions and did not provide any additional insight. 
In addition to the sub-monoamide mass region, a new peak is observed at $m / z=310.2$ as well as at values slightly higher than the $\mathrm{m} / z=312.2$ of the monoamide. The product observed at $m / z=310.2$ corresponds to the abstraction of 2 hydrogen atoms from the ligand to form a $\mathrm{C}=\mathrm{C}$ bond within the monoamide framework. This product was observed regardless acid concentration and air sparging conditions. For samples in contact with the aqueous phase the species most likely to react by $\mathrm{H}$-atom abstraction is the ${ }^{\circ} \mathrm{OH}$ radical, which reacts with alkanes with fast rate constants. The same product was found under aqueous-free conditions. In this case, the monoamide may react with dodecane radical cations by electron transfer. This has been reported previously for the diglycolamides. ${ }^{[18]}$ If so, the loss of H-atoms may occur through proton elimination by the resulting monoamide radical cation.

Addition of an ${ }^{\circ} \mathrm{OH}$ radical to the $\mathrm{m} / \mathrm{z}=310.2$ ion would generate the ion seen at $m / z=328.0$. However, this product was also observed in the organic-only solution and another oxidative mechanism may account for its appearance. The product at $\mathrm{m} / \mathrm{z}=258.2$ could be produced either by carbonyl $\mathrm{C}-\mathrm{N}$ bond rupture of the parent monoamide, or by $\mathrm{H}$-atom abstraction from the amine $\mathrm{N}-\mathrm{H}$ bond of DEHA, followed by addition of $\mathrm{OH}$ to generate di-2-ethylhexylhydroxylamine. This probably results from simple ${ }^{\circ} \mathrm{OH}$ radical addition to the produced ${ }^{\circ} \mathrm{N}$ radical. This product was observed only in air-sparged solutions at both acid concentrations. The product at $\mathrm{m} / \mathrm{z}=200.2$ corresponds to a $\mathrm{C}-\mathrm{N}$ bond rupture resulting in the loss of one of the 2ethylhexyl groups to produce mono-2-ethylhexyl-isobutyramide (EHiBA). This species was detected more at lower absorbed doses in the organic-only samples than in the $4 \mathrm{M} \mathrm{HNO}_{3}$ contacted samples, suggesting that it is susceptible to acid hydrolysis.

For products of higher molecular weight, Figure 7, new species appeared at $\mathrm{m} / \mathrm{z}=551.7$, $533.5,480.5$, and 410.5 . Spectra generated by $\mathrm{MS}^{2}$ fragmentation suggest that $\mathrm{m} / z=551.7$ is an addition product of the monoamide with the amine DEHA. Two addition species between the 
dodecane or degradation products were identified at $\mathrm{m} / \mathrm{z}=480.5$ (monoamide + dodecane) and 410.5 (DEHA + dodecane). These high molecular weight species are likely produced by the addition reactions of the carbon-centered radicals generated by $\mathrm{H}$-atom abstractions from the corresponding reactants. The peak at $\mathrm{m} / \mathrm{z}=533.5$ remains unidentified.

Interestingly, the higher molecular weight products were observed to have the highest intensities in the samples not contacted with an aqueous phase during irradiation (Figure 7). For samples irradiated in the presence of $0.1 \mathrm{M} \mathrm{HNO}_{3}$, the abundance of these species was less intense. In the spectra of the samples irradiated in the presence of $4 \mathrm{M} \mathrm{HNO}_{3}$ these species are completely absent. This indicates that the carbon-centered radicals were scavenged by produced ${ }^{\circ} \mathrm{NO}_{3}$ radicals under those conditions, although it must be noted that no nitro-substituted species were detected. Many of these nitro- or hydroxy-substituted species may have partitioned to the aqueous phase.

It is clear that the presence of acid during irradiation of the monoamide ligand impacts the formation of higher molecular weight species. Thus, there appears to be competitive degradation pathways for DEHiBA degradation; an acid promoted pathway and an acid independent pathway. Scheme 1 shows the proposed formation of low molecular weight degradation products for all three conditions. Scheme 2 shows the proposed formation for the higher molecular weight products in the absence of acid.

This conclusion correlates well with the FT-IR data collected by supporting the observation that the samples irradiated in the presence of acid resulted in new peaks in the spectrum, whereas the organic only samples showed no difference when compared to an unirradiated monoamide solution. Interestingly, although the product distribution is affected by contact with the acidic aqueous phase, the overall rate of monoamide degradation is not. 


\section{Aqueous phase ESI-MS analysis}

To aid in the understanding of the impact of acid during irradiation on monoamide degradation, the aqueous phase was next analyzed to determine if degradation products could be observed. All ions detected in the aqueous phase are shown in the Supplementary Information, Table S2. The nature of the species identified in the aqueous phase by ESI-MS appears to depend on nitric acid concentration. Figure 8 shows the spectra of the $0.1 \mathrm{M} \mathrm{HNO}_{3}$ irradiated $\mathrm{DEH} i \mathrm{BA}$ aqueous phase and Figure 9 shows the $4 \mathrm{M} \mathrm{HNO}_{3}$ sample. There are more species present in the 4 $\mathrm{M} \mathrm{HNO}_{3}$ sample than in the $0.1 \mathrm{M} \mathrm{HNO}_{3}$ sample.

The products DEHA $(m / z=242.2)$ and $\operatorname{EH} i \mathrm{BA}(\mathrm{m} / \mathrm{z}=200.2)$ were found in both the $0.1 \mathrm{M}$ and 4.0 $\mathrm{M} \mathrm{HNO}_{3}$ aqueous phases of the irradiated samples, with maximum signal strength in the samples irradiated between 500-750 kGy. A new product was detected at $\mathrm{m} / \mathrm{z}=130.3$, identified as 2-ethylhexyl-amine, indicating loss of both a butyl and one ethylhexyl group, likely produced by continued radiolysis of either DEHA or EHiBA. The detected signals of DEHA and EH $i \mathrm{BA}$ in the aqueous phase decreased at higher absorbed doses, suggesting that these species are susceptible to continued radiolysis in the aqueous phase, and as their signals decreased, the highintensity signal at $\mathrm{m} / \mathrm{z}=130.3$ (2-ethylhexylamine) grew in. This signal continued to increase to a maximum at the highest absorbed dose of $1000 \mathrm{kGy}$.

Other unidentified ions whose signals increase in abundance with increasing dose in the 4.0 $\mathrm{M} \mathrm{HNO}_{3}$ air-sparged samples were $\mathrm{m} / \mathrm{z}=126.2$ (possibly $\mathrm{C}_{8} \mathrm{H}_{15} \mathrm{~N}$, a doubly unsaturated mono-alkyl amine), and $m / z=142.2$ (possibly $\mathrm{C}_{8} \mathrm{H}_{15} \mathrm{~N}$ ). The continued degradation of the DEHA and $\mathrm{EH} i \mathrm{BA}$ to lower molecular weight, highly oxidized species was favored under the oxidizing conditions of aeration in the presence of high $\mathrm{HNO}_{3}$ concentration. Small amounts of the parent monoamide were also identified in the aqueous phase. In previous studies, authors reported the formation of carboxylic acid by rupture of the carbonyl-N bond. ${ }^{[8,9,14,15]}$ In the case of DEHiBA, 
the carboxylic acid expected to form is butanoic acid. This species was not detected in either the organic or aqueous phases. This is likely due to the hrdrolytic degradation of the species resulting in the formation of lower molecular weight species which are too low to be detected by the analytical method used.

\section{Effects of irradiation on uranium solvent extraction}

The $D_{\mathrm{U}}$ for the extraction of non-irradiated DEH $i \mathrm{BA}$ was consistent with expectations based on literature results. ${ }^{[2,4]}$ It can be seen in Figure 10 that within the $\pm 8 \%$ uncertainty, there was no change in uranium extraction efficiency with absorbed dose to the maximum of $1000 \mathrm{kGy}$ under any irradiation condition. This is consistent with the high stability of DEHiBA under all conditions, the generation of decomposition products such as EHiBA, compounds with $\mathrm{m} / \mathrm{z}=310$ and 326 (DEHiBA with a $\mathrm{C}=\mathrm{C}$ bond and a $\mathrm{C}=\mathrm{O}$ bond), and high molecular weight compounds $(\mathrm{m} / \mathrm{z}=480,551)$ that are likely also extractants, as well as the excess initial concentration of the ligand in comparison with the tracer metal concentration $(0.01 \mathrm{mM})$. It can also be seen that the stripping $D_{\mathrm{U}}$ appears to gradually decrease with absorbed dose. This may be a result of the presence of DEHiBA radiolysis products in the aqueous strip solution, and the corresponding stripping of uranium by these species. Although the decreases in $D_{\mathrm{U}}$ are not large, decreased stripping distribution ratios can only be considered to be advantageous to a process separation.

\section{CONCLUSIONS}

In contrast to previous literature claiming exceptional radiation stability for the monoamides, the degradation rate of $\mathrm{DEH} i \mathrm{BA}$ is actually similar to that of TBP and the malonamides. It is slow compared to the DGAs, and unaffected by contact with an aqueous phase or aeration. However, radiolytic product distributions vary with irradiation conditions. Based on these results, DEHiBA apparently undergoes degradation via two pathways: an acid promoted pathway, and an 
acid independent pathway. It is clear that the monoamide degrades when irradiated in the presence of an aqueous phase to form a series of lower molecular weight species generated from the cleavage of the $\mathrm{C}-\mathrm{N}$ amide bond or $\mathrm{C}-\mathrm{N}$ amine bond. As this is the active site during synthesis, it is not surprising that this is the weak point in the ligand structure. The main degradation products appear to be the secondary amide DEHA and the amine EHiBA. These species, and the smaller fragments produced by their radioysis have increased solubility in the aqueous phase. Another product common to all irradiation conditions was the species at $\mathrm{m} / \mathrm{z}=310.2$, which is identified as an unsaturated derivative of DEH $i \mathrm{BA}$, resulting from the loss of two H-atoms.

In contrast, when an aqueous phase is not present, higher molecular weight products are generated via carbon radical addition reactions under the more reducing conditions. These products have maximum abundance at $750 \mathrm{kGy}$, and then decrease with increasing absorbed dose. Their significance to a biphasic solvent extraction process is probably inconsequential.

Solvent extraction results show that DEH $i \mathrm{BA}$ radiolytic degradation had little effect on uranium distribution ratios even at absorbed doses as high as $1 \mathrm{MGy}$. The build-up of degradation products in the aqueous phase apparently decreased stripping distribution ratios, which is not adverse to a process application. Thus, these findings for $\mathrm{DEH} i \mathrm{BA}$ are in agreement with previous work that claimed generation of inoffensive radiolysis products for the monoamides. ${ }^{[8 \text {, }}$ $11,13,25]$ This, in addition to their CHON nature, suggests that they are good candidates for the development of advanced fuel cycles. Interesting future work will include a comparison study on the $n$-alkane monoamide DEHBA that extracts more $\mathrm{Pu}(\mathrm{IV})$ in the organic phase and is therefore more likely to undergo radiolysis effects in potential nuclear fuel recycling processes.

\section{REFERENCES}


1. Gasparini, G. M. and Grossi, G., Long-chain disubstituted aliphatic amides as extracting agents in industrial applications of solvent-extraction, Solvent Extraction and Ion Exchange, 1986, 4, 12331271.

2. Siddall, T. H., Effects of structure of $\mathrm{N}, \mathrm{N}$-disubstituted amides on their extraction of actinide and zirconium nitrates and of nitric acid, Journal of Physical Chemistry, 1960, 64, 1863-1866.

3. Pathak, P. N., Kumbhare, L. B. and Manchanda, V. K., Structural effects in N,N-dialkyl amides on their extraction behavior toward uranium and thorium, Solvent Extraction and lon Exchange, 2001, 19, 105-126.

4. Prabhu, D. R., Mahajan, G. R. and Nair, G. M., Di(2-ethyl hexyl)butyramide and di(2-ethyl hexyl)isobutyramide as extractants for uranium(VI) and plutonium(IV), Journal of Radioanalytical and Nuclear Chemistry, 1997, 224, 113-117.

5. Mowafy, E. A., The effect of previous gamma-irradiation on the extraction of U(VI), $\operatorname{Th}(\mathrm{IV}), \mathrm{Zr}(\mathrm{IV})$, $\mathrm{Eu}(\mathrm{III})$ and Am(III) by various amides, Journal of Radioanalytical and Nuclear Chemistry, 2004, 260, 179-187.

6. Ruikar, P. B., Nagar, M. S. and Subramanian, M. S., Extraction behavior of uranium, plutonium and some fission-products with gamma-irradiated n,n'-dialkylamides, Journal of Radioanalytical and Nuclear Chemistry-Articles, 1992, 159, 167-173.

7. Ruikar, P. B., Nagar, M. S. and Subramanian, M. S., Extraction of uranium, plutonium and some fission-products with gamma-irradiated unsymmetrical and branched-chain dialkylamides, Journal of Radioanalytical and Nuclear Chemistry-Letters, 1993, 176, 103-111.

8. Parikh, K. J., Pathak, P. N., Misra, S. K., Tripathi, S. C., Dakshinamoorthy, A. and Manchanda, V. K., Radiolytic Degradation Studies on N,N-dihexyloctanamide (DHOA) under PUREX Process Conditions, Solvent Extraction and Ion Exchange, 2009, 27, 244-257.

9. Pathak, P. N., Prabhu, D. R., Kanekar, A. S. and Manchanda, V. K., in Actinides 2009, IOP Conference Series-Materials Science and Engineering, eds. L. Rao, J. G. Tobin and D. K. Shuh, 2010, vol. 9.

10. Ruikar, P. B., Nagar, M. S., Subramanian, M. S., Gupta, K. K., Varadarajan, N. and Singh, R. K., Extraction behavior of uranium(VI), plutonium(IV) and some fission-products with gamma-preirradiated n-dodecane solutions of N,N'-dihexyl substituted amides, Journal of Radioanalytical and Nuclear Chemistry-Articles, 1995, 196, 171-178.

11. Pathak, P. N., Prabhu, D. R., Ruikar, P. B. and Manchanda, V. K., Evaluation of Di(2éthylhexyl)isobutyramide (D2EHiBA) as a process extractant for the recovery of ${ }^{233} \mathrm{U}$ from irradiated Th, Solvent Extraction and lon Exchange, 2002, 20, 293-311.

12. Manchanda, V. K. and Pathak, P. N., Amides and diamides as promising extractants in the back end of the nuclear fuel cycle: an overview, Separation and Purification Technology, 2004, 35, 85103.

13. Berthon, L. and Charbonnel, M. C., Radiolysis of Solvents Used in Nuclear Fuel Reprocessing, Ion Exchange and Solvent Extraction A Series of Advances, 2010, 19, 429-513.

14. Musikas, C., Solvent-extraction for the chemical separations of the $5 f$ elements, Inorganica Chimica Acta, 1987, 140, 197-206.

15. Musikas, C., Potentiality of nonorganophosphorus extractants in chemical separations of actinides, Separation Science and Technology, 1988, 23, 1211-1226.

16. Mincher, B., Modolo, G. and Mezyk, S., Review Article: The Effects of Radiation Chemistry on Solvent Extraction: 1. Conditions in Acidic Solution and a Review of TBP Radiolysis, Solvent Extraction and lon Exchange, 2009, 27, 1-25. 
17. Fricke, H., Hart,E., The chemical action of Roentgen rays on dilute ferrosulphate solutions as a measure of dose., Am. J Roent. Radium Ther. Nucl. Med., 1927, 18, 430-432.

18. Zarzana, C. A., Groenewold, G. S., Mincher, B. J., Mezyk, S. P., Wilden, A., Schmidt, H., Modolo, G., Wishart, J. F. and Cook, A. R., A Comparison of the gamma-Radiolysis of TODGA and T(EH)DGA Using UHPLC-ESI-MS Analysis, Solvent Extraction and lon Exchange, 2015, 33, 431-447.

19. Galan, H., Zarzana, C. A., Wilden, A., Nunez, A., Schmidt, H., Egberink, R. J. M., Leoncini, A., Cobos, J., Verboom, W., Modolo, G., Groenewold, G. S. and Mincher, B. J., Gamma-radiolytic stability of new methylated TODGA derivatives for minor actinide recycling, Dalton Transactions, 2015, 44, 18049-18056.

20. Roscioli-Johnson, K. M., Zarzana, C. A., Groenewold, G. S., Mincher, B. J., Wilden, A., Schmidt, H., Modolo, G. and Santiago-Schübel, B., A Study of the $\gamma$-Radiolysis of $\mathrm{N}, \mathrm{N}$-Didodecyl- $\mathrm{N}^{\prime}, \mathrm{N}^{\prime}$ Dioctyldiglycolamide Using UHPLC-ESI-MS Analysis, Solvent Extraction and Ion Exchange, 2016, 34, 439-453.

21. Berthon, L., Morel, J. M., Zorz, N., Nicol, C., Virelizier, H. and Madic, C., Diamex process for minor actinide partitioning: Hydrolytic and radiolytic degradations of malonamide extractants, Separation Science and Technology, 2001, 36, 709-728.

22. Adamov, V. M., Andreev, V. I., Belyaev, B. N., Markov, G. S., Polyakov, M. S., Ritari, A. E. and Shil'nikov, A. Yu, Radiolysis of an extraction system based on solutions of tri-n-butylphosphate in hydrocarbon diluents, Sov. Radiochem., 1988, 29, 775-781.

23. Condamines, $\mathrm{N}$. and Musikas, C., The extraction by $\mathrm{N}, \mathrm{N}$ - dialkylamides.I. $\mathrm{HNO}_{3}$ and other inorganic acids, Solvent Extraction and lon Exchange, 1988, 6 (6), 1007-1034.

24. Dejugnat, C., Berthon, L., Dubois, V., Meridiano, Y., Dourdain, S., Guillaumont, D., PelletRostaing, S. and Zemb, T., Liquid-liquid extraction of acids and water by a malonamide: I-anion specific effects on the polar core microstructure of the aggregated malonamide, Solvent Extraction and lon Exchange, 2014, 32, 601-619.

25. Gasparini, G. M. and Grossi, G., Application of n,n-dialkyl aliphatic amides in the separation of some actinides, Separation Science and Technology, 1980, 15, 825-844. 


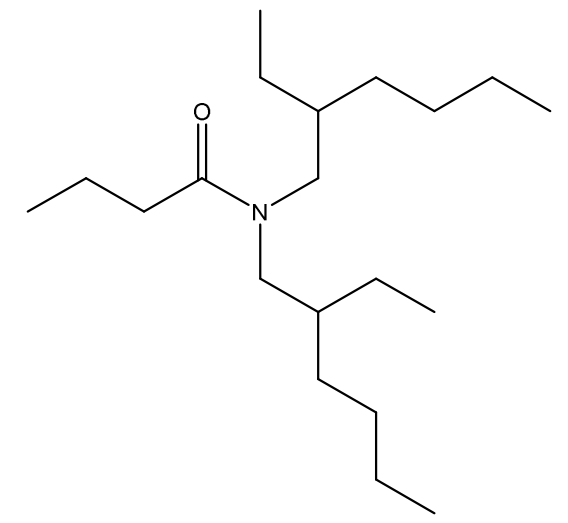

a

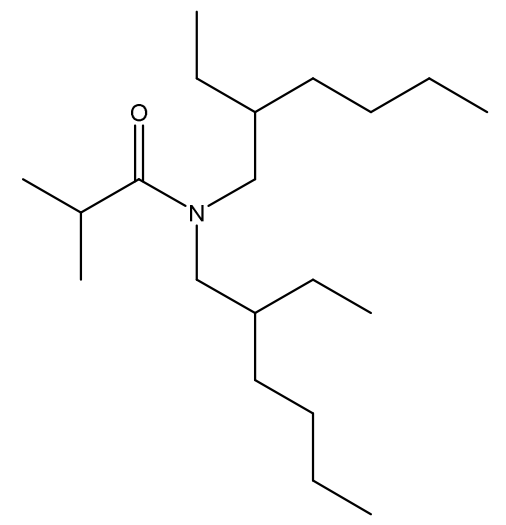

b.

Figure 1: Structure of di-2-ethylhexyl-butyramide (DEHBA), (a) and di-2-ethylhexylisobutyramide (DEHiBA), (b). 

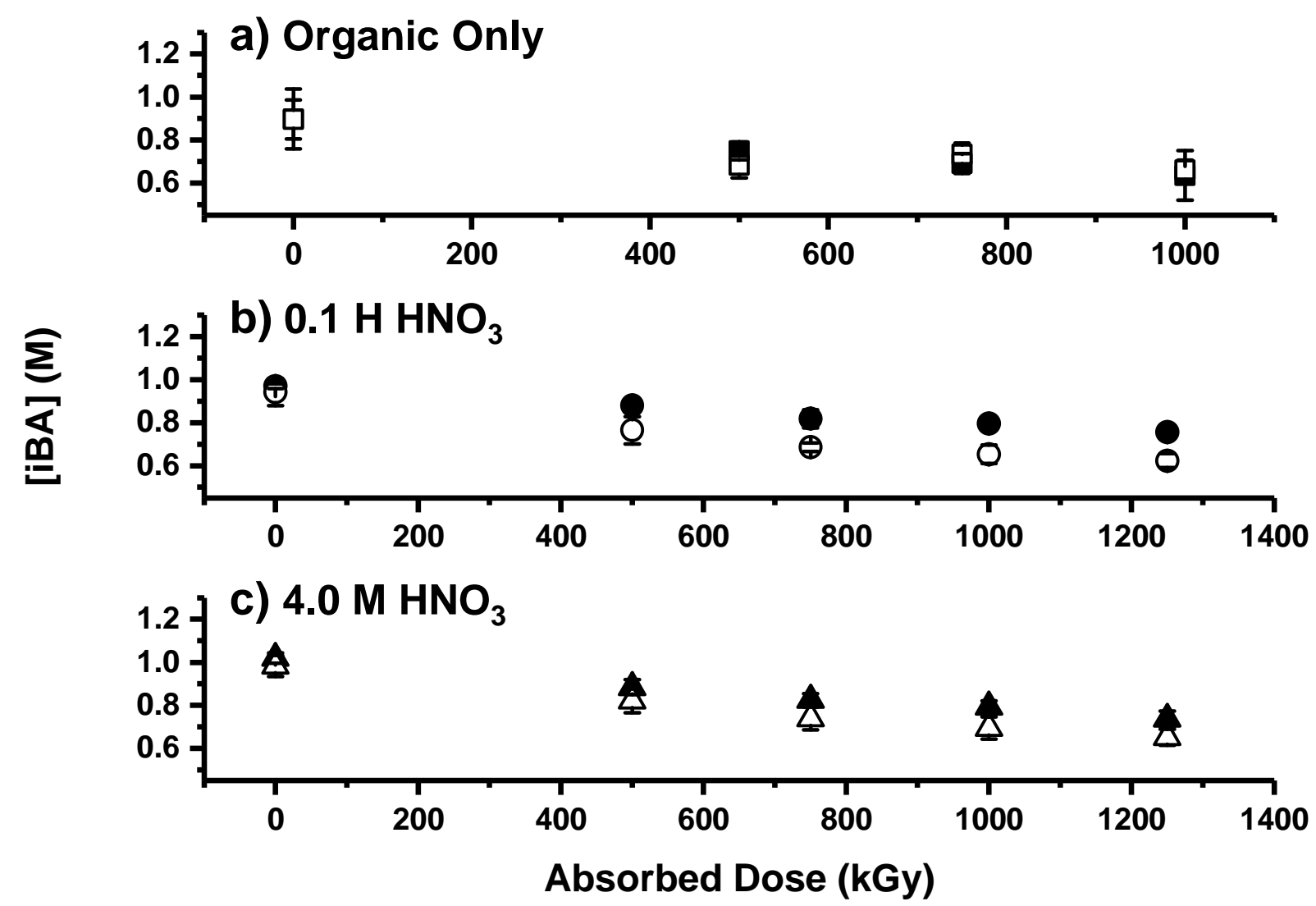

Figure 2: DEH $i$ BA concentration in the organic phase as a function of absorbed dose, for a) the unsparged organic phase only (solid squares); organic phase with air sparging (open squares); b) unsparged organic phase in contact with $0.1 \mathrm{M} \mathrm{HNO}_{3}$ (solid circles); organic phase in contact with $0.1 \mathrm{M} \mathrm{HNO}_{3}$ with air sparging (open circles); c) unsparged organic phase in contact with 4 $\mathrm{M} \mathrm{HNO}_{3}$ (solid triangles); and organic phase in contact with $4 \mathrm{M} \mathrm{HNO}_{3}$ with air sparging (open triangles). Each datum for the two organic-only samples is the mean of five injections measured by UHPLC-ESI-MS, while each datum for the $0.1 \mathrm{M}$ and $4.0 \mathrm{M} \mathrm{HNO}_{3}$-contacted samples is the mean of 3 injections measured by GC-FID. Error bars represent $99 \%$ confidence intervals. 


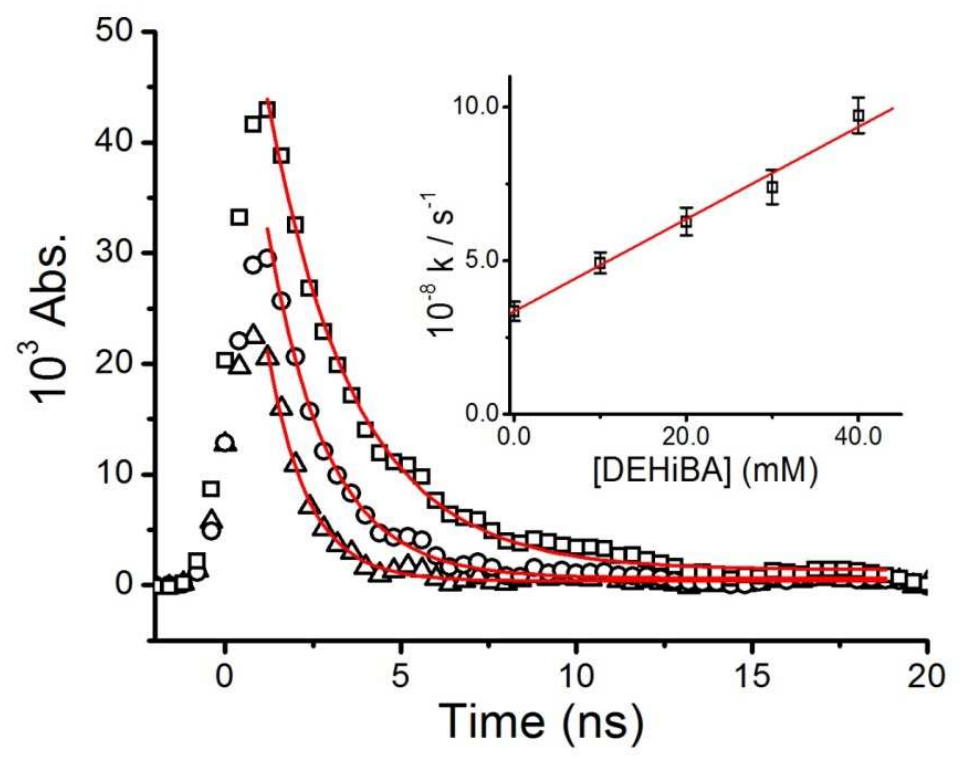

Figure 3: Transient absorption decays measured at $800 \mathrm{~nm}$ for dodecane radical cation reaction with 10 (open squares), 20 (open circles) and 40 (open triangles) mM DEH $i \mathrm{BA}$ in dodecane at $22{ }^{\circ} \mathrm{C}$. Solid lines are fitted double-exponential decays. Inset: Rate constant determination using fast exponent fit values from kinetic traces. The slope of this line corresponds to a second-order rate constant of $\mathrm{k}=(1.52 \pm 0.11) \times 10^{10} \mathrm{M}^{-1} \cdot \mathrm{s}^{-1}, \mathrm{R}^{2}=0.99$. 


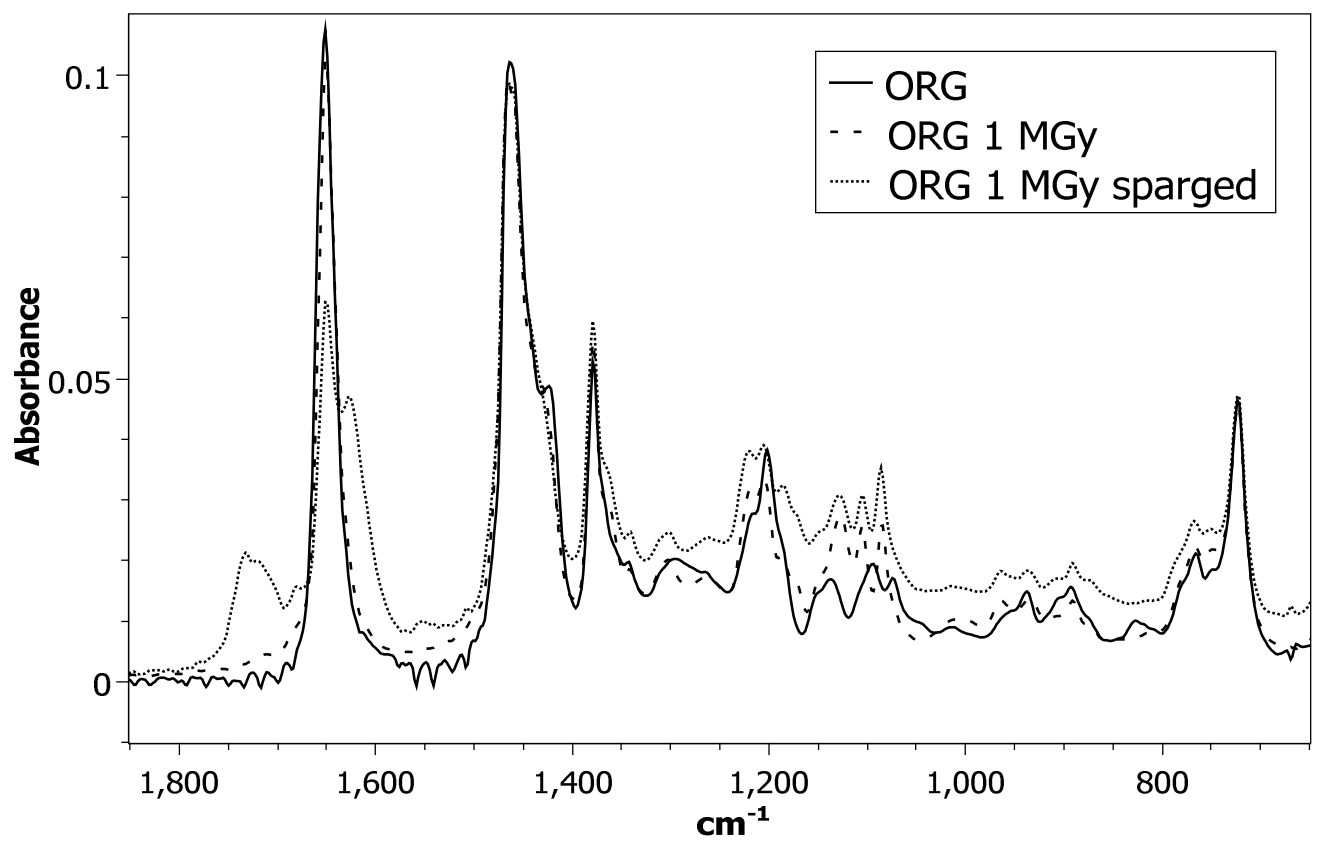

Figure 4: FTIR spectra of $1 \mathrm{M}$ DEH $i \mathrm{BA}$ dissolved in dodecane (solid black line), $1 \mathrm{M}$ DEH $i \mathrm{BA}$ dissolved in dodecane irradiated to $1 \mathrm{MGy}$ (dashed line), $1 \mathrm{M}$ DEH $i \mathrm{BA}$ dissolved in dodecane irradiated to $1 \mathrm{MGy}$ under air-sparging conditions (dotted line). 


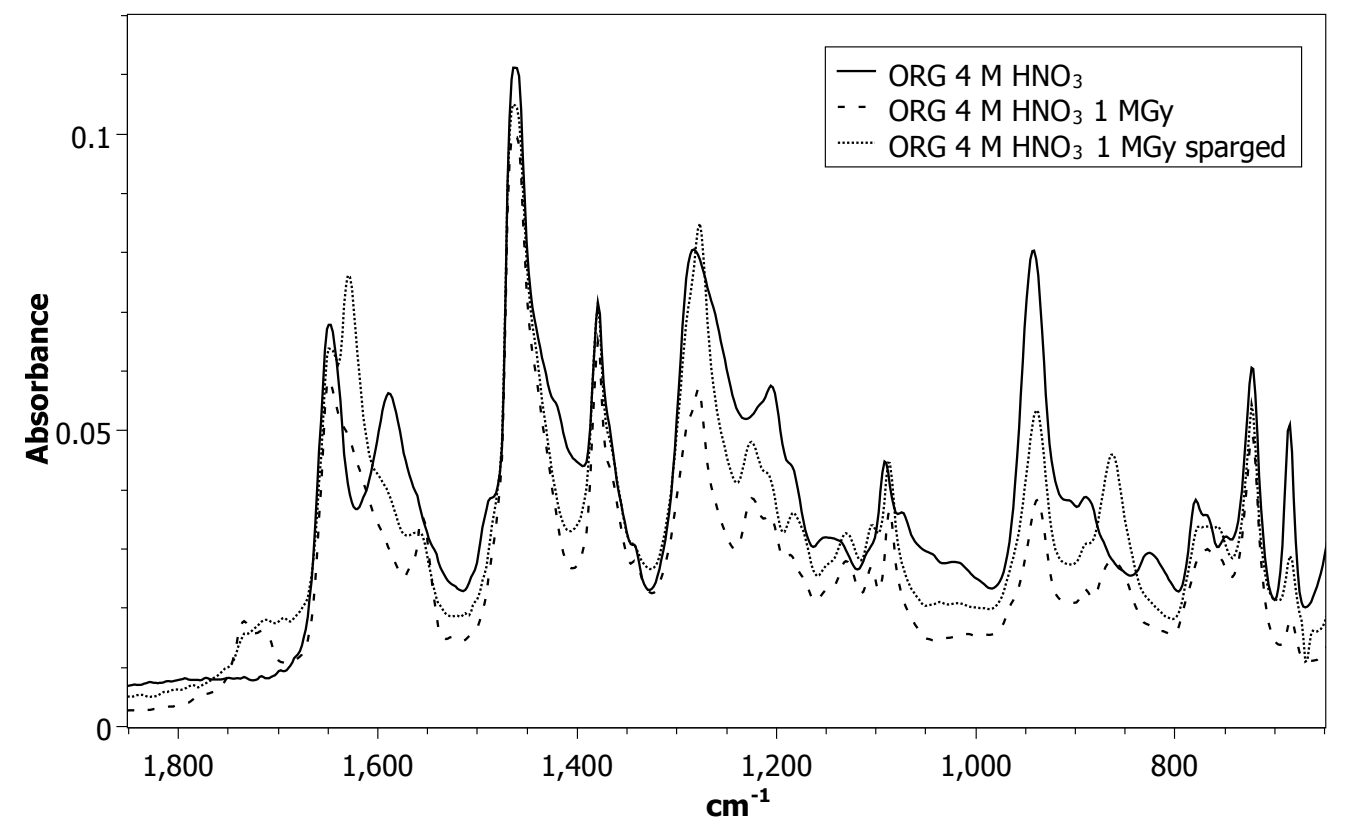

Figure 5: FTIR spectra of $1 \mathrm{M} \mathrm{DEH} i \mathrm{BA}$ dissolved in dodecane contacted with $4 \mathrm{M} \mathrm{HNO}_{3}$ (solid black line), $1 \mathrm{M}$ DEH $i \mathrm{BA}$ dissolved in dodecane irradiated to $1 \mathrm{MGy}$ while in contact with $4 \mathrm{M}$ $\mathrm{HNO}_{3}$ (dashed line), $1 \mathrm{M} \mathrm{DEH} i \mathrm{BA}$ dissolved in dodecane irradiated to $1 \mathrm{MGy}$ and air-sparged while in contact with $4 \mathrm{M} \mathrm{HNO}_{3}$ (dotted line). 


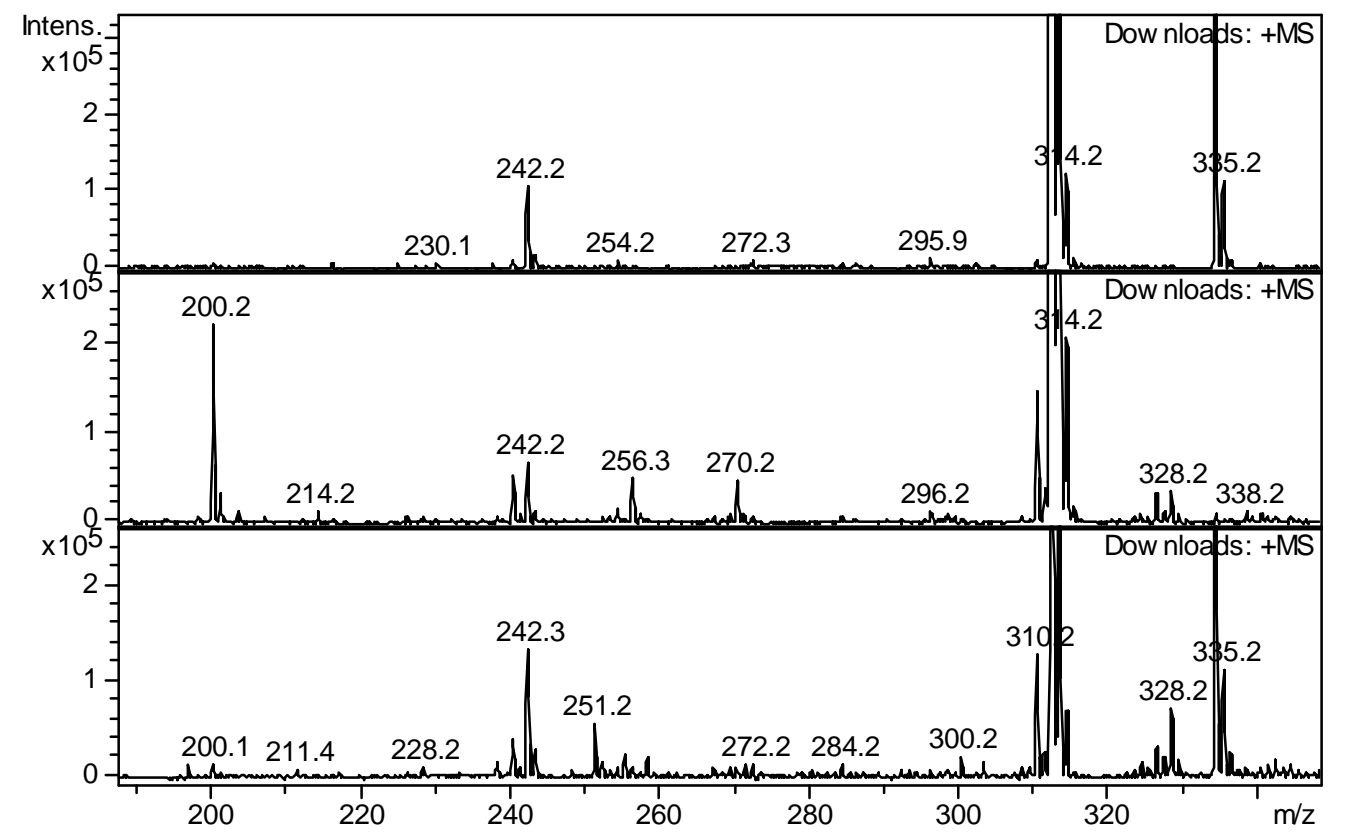

Figure 6: ESI-MS spectra of DEH $i \mathrm{BA}$ at $0 \mathrm{kGy}$ (top), $1000 \mathrm{kGy}$ organic phase only (middle), $1000 \mathrm{kGy}$ contacted with $4 \mathrm{M} \mathrm{HNO}_{3}$ (bottom). All spectra were recorded in positive ionization mode, trap drive 50, skimmer voltage $30 \mathrm{~V}$, non-air sparged. Note: the intensity scale was chosen to specifically show the lower abundance species. 


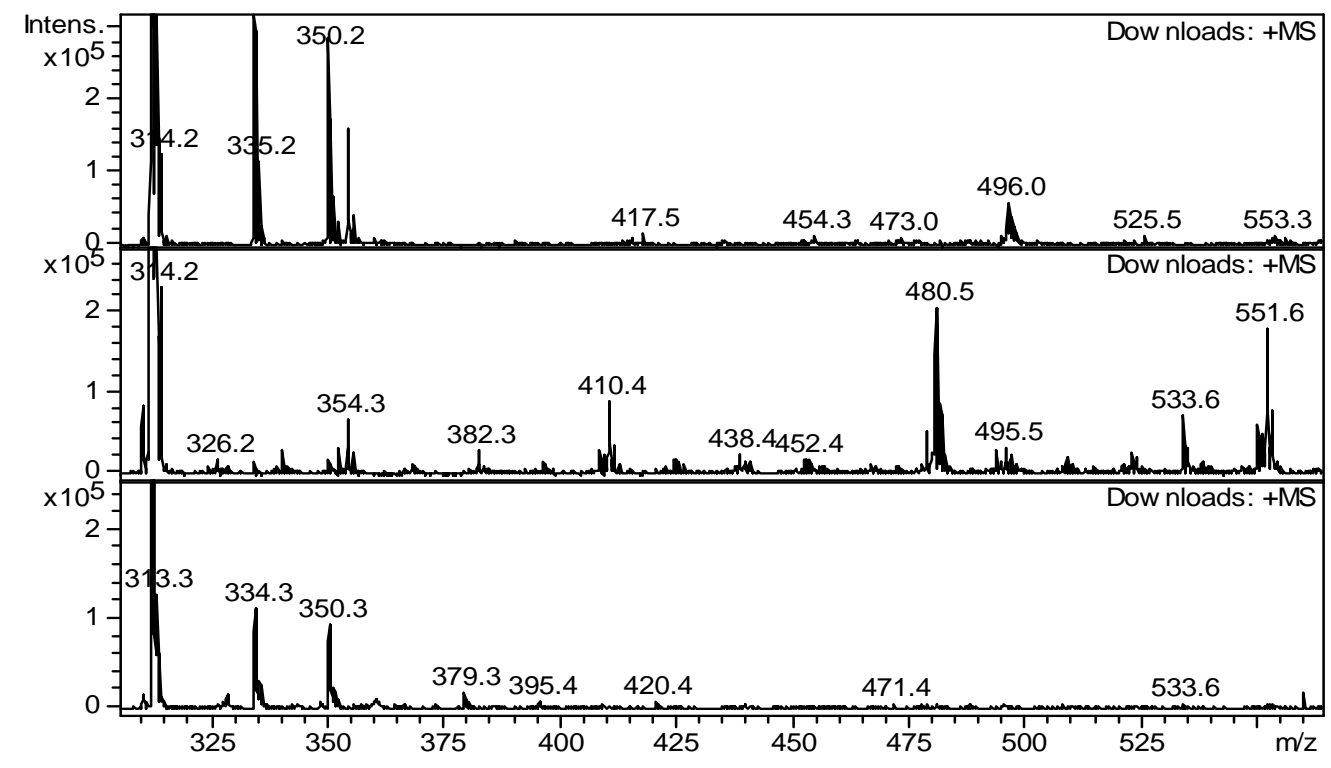

Figure 7: ESI-MS spectra of DEHiBA at $0 \mathrm{kGy}$ (top), $750 \mathrm{kGy}$ organic phase only (middle), 750 $\mathrm{kGy}$ contacted with $4 \mathrm{M} \mathrm{HNO}_{3}$ (bottom). All spectra were recorded in positive ionization mode, trap drive 50, skimmer voltage $30 \mathrm{~V}$, non-air sparged. Note: the intensity scale was chosen to specifically show the lower abundance species. 


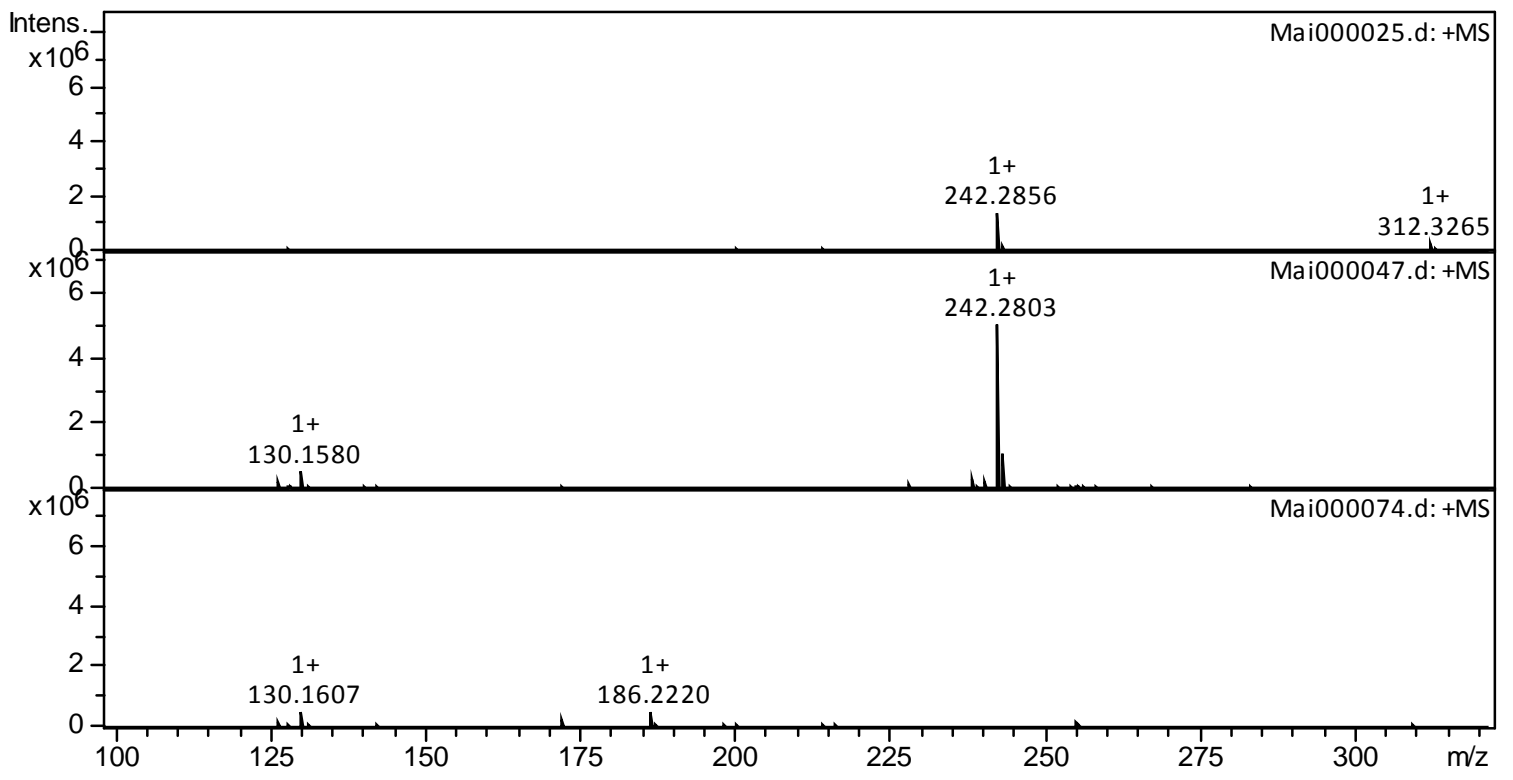

Figure 8: ESI-MS spectra of $0.1 \mathrm{M} \mathrm{HNO}_{3}$ aqueous phase irradiated with DEHiBA at $0 \mathrm{kGy}$ (top), $500 \mathrm{kGy}$ (middle), $1000 \mathrm{kGy}$ (bottom). All spectra were recorded in positive ionization mode, trap drive 50, skimmer voltage $30 \mathrm{~V}$, air sparged. 


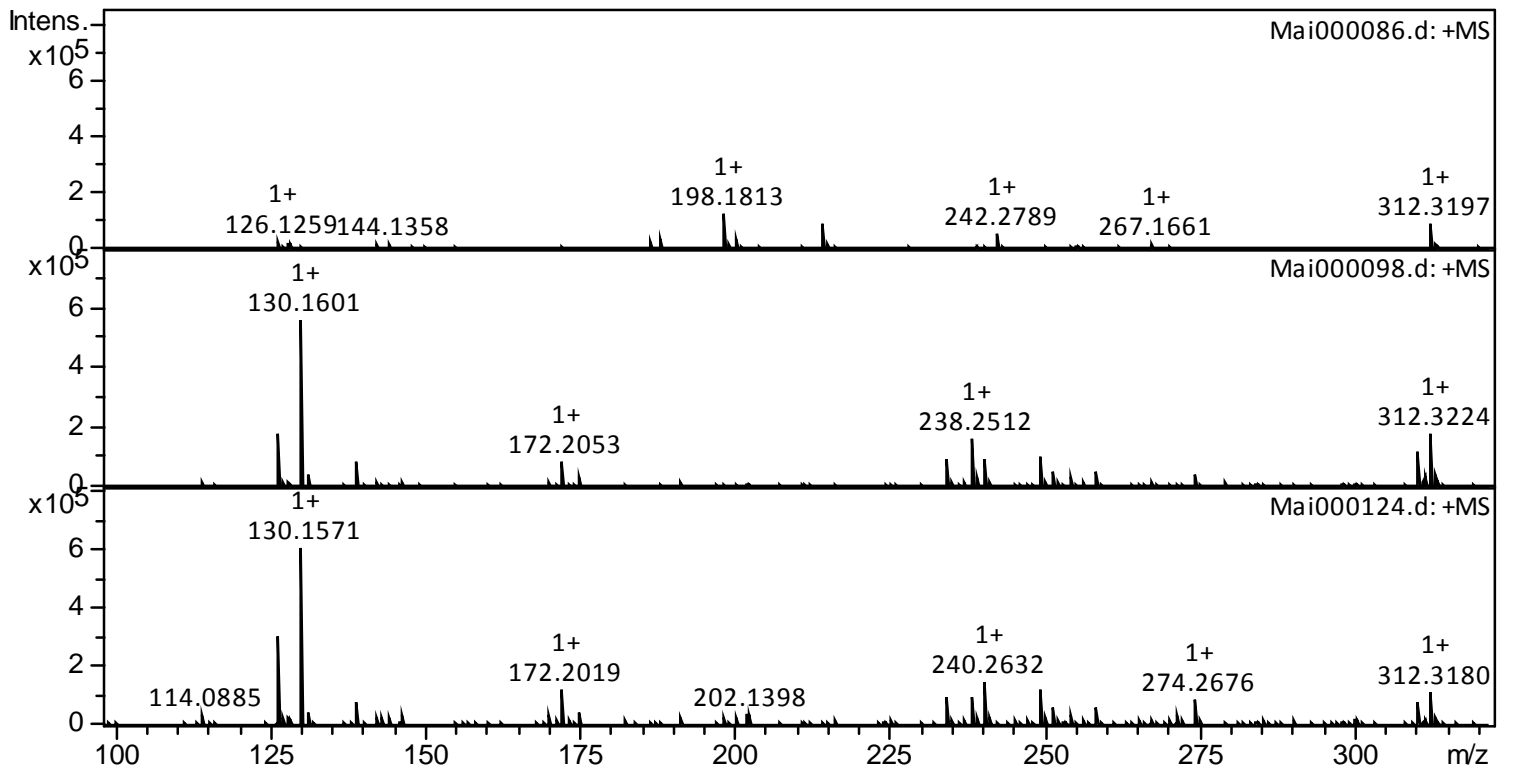

Figure 9: ESI-MS spectra of $4 \mathrm{M} \mathrm{HNO}_{3}$ aqueous phase irradiated with DEHiBA at $0 \mathrm{kGy}$ (top), $500 \mathrm{kGy}$ (middle), $1000 \mathrm{kGy}$ (bottom). All spectra were recorded in positive ionization mode, trap drive 50, skimmer voltage $30 \mathrm{~V}$, air-sparged. 


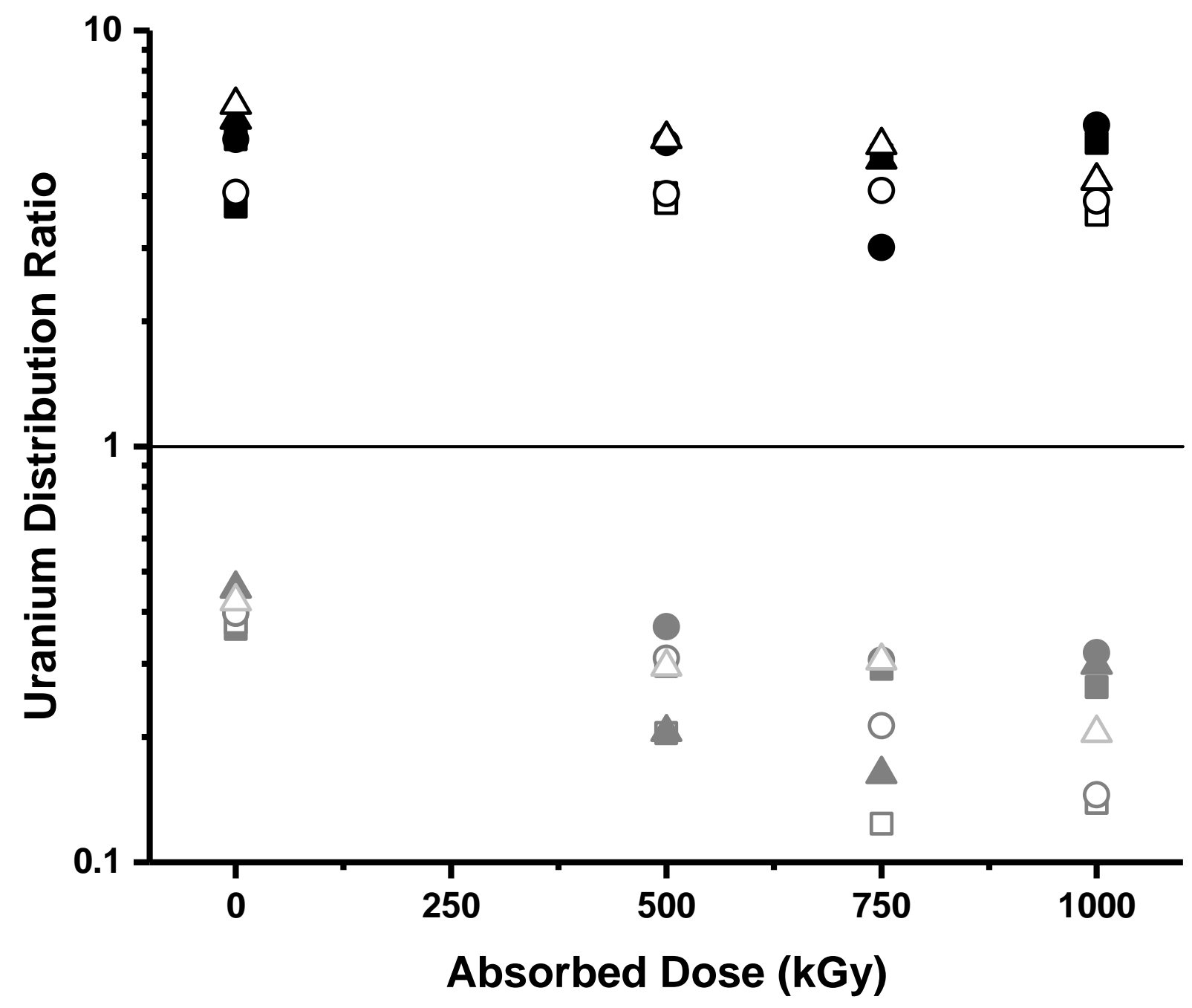

Figure 10: Uranium solvent extraction $\left(\mathrm{D}_{\mathrm{U}}\right)$ from $6.5 \mathrm{M} \mathrm{HNO}_{3}$, (black symbols) and stripping (with $0.1 \mathrm{M} \mathrm{HNO}_{3}$ ), (grey symbols) using irradiated, initially $1 \mathrm{M}$ DEHiBA in dodecane. Irradiated organic phase only (solid squares); sparged organic phase (open squares); contact with $0.1 \mathrm{M} \mathrm{HNO}_{3}$ (solid circles); sparged contact with $0.1 \mathrm{M} \mathrm{HNO}_{3}$ (open circles); contact with $4 \mathrm{M}$ $\mathrm{HNO}_{3}$ (solid triangles); and sparged contact with $4 \mathrm{M} \mathrm{HNO}_{3}$ (open triangles). Mean error bars of $\pm 8 \%$ omitted for clarity. 


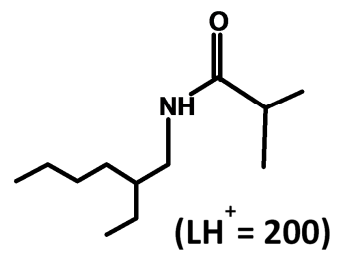

EHIBA

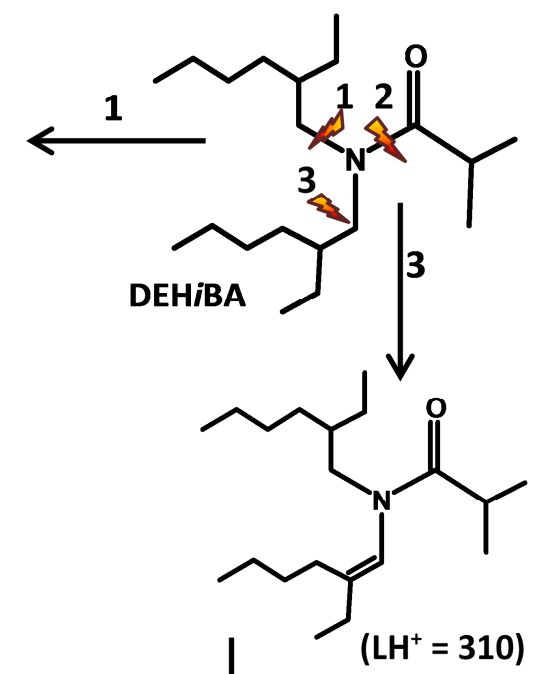

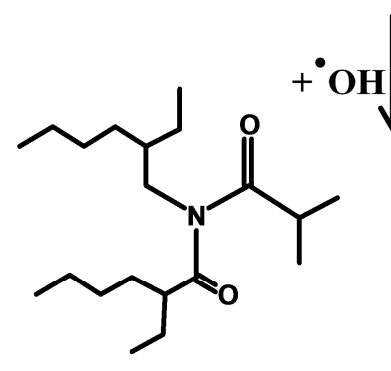

$\left(\mathrm{LH}^{+}=326\right)$<smiles>CCCCC(CC)CNCC(CC)CCCC</smiles>

$$
(\mathrm{LH}=242) \quad\left(\mathrm{LH}^{+}=240\right)
$$$$
+\stackrel{\circ}{O H}
$$<smiles>CCCCC(CC)CNC(=O)C(CC)CCCC</smiles><smiles>CCCCC(CC)CC</smiles><smiles>CCCCC(CC)C(O)NC</smiles>

$\left(\mathrm{LH}^{+}=256\right) \quad\left(\mathrm{LH}^{+}=258\right)$

Scheme 1: Proposed DEHiBA degradation pathway for the formation of low molecular weight species. 


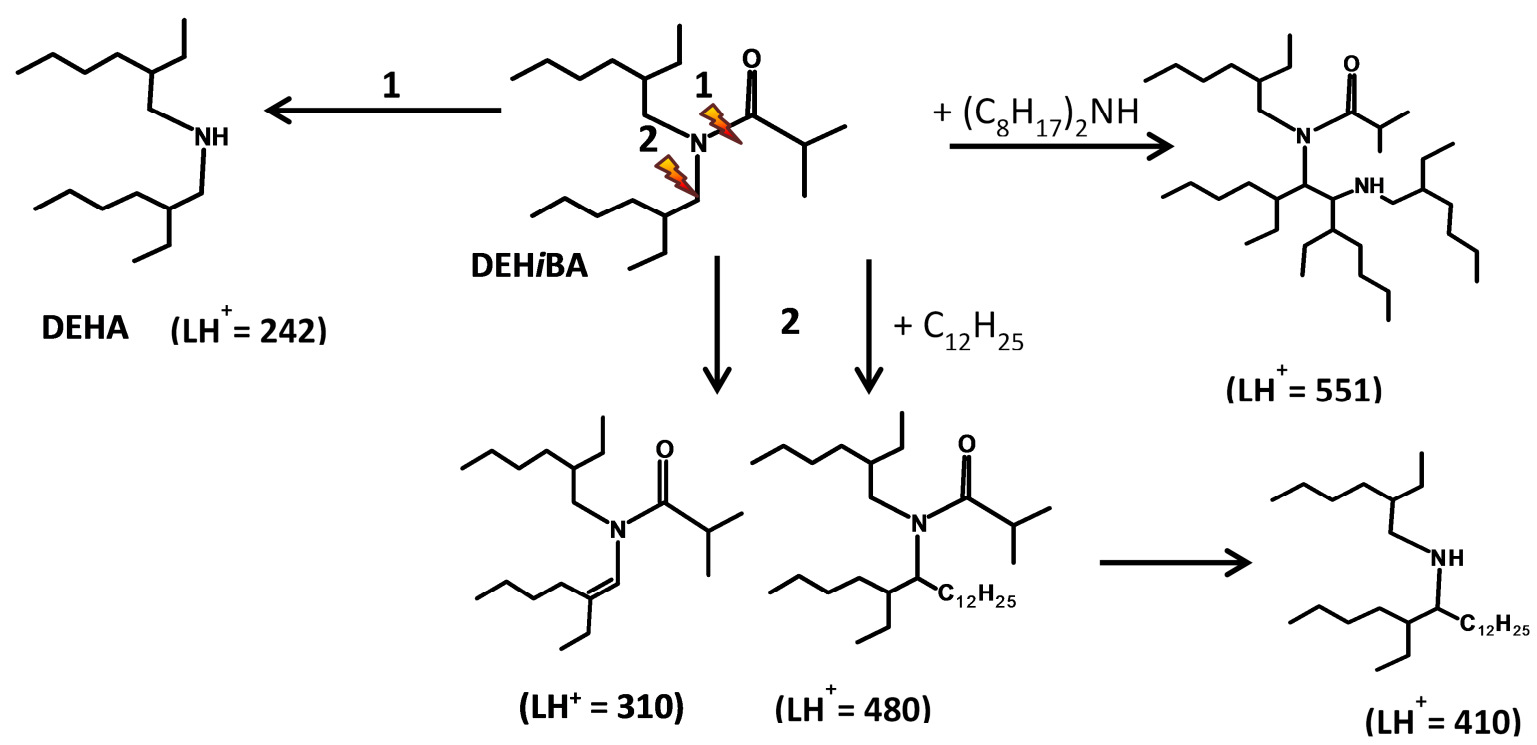

Scheme 2: Proposed DEHiBA degradation pathway for the formation of high molecular weight species in the absence of acid. 


\begin{tabular}{ll}
\hline Condition & Dose Constant $(d)\left(\mathrm{kGy}^{-1}\right)$ \\
\hline Organic Only - Unsparged & $(3.5 \pm 1.4) \times 10^{-4}$ \\
Organic Only - Sparged & $(3.0 \pm 1.2) \times 10^{-4}$ \\
$0.1 \mathrm{M} \mathrm{HNO}_{3}$ Contacted - Unsparged & $(2.6 \pm 0.6) \times 10^{-4}$ \\
$0.1 \mathrm{M} \mathrm{HNO}_{3}$ Contacted - Sparged & $(3.4 \pm 0.7) \times 10^{-4}$ \\
$4.0 \mathrm{M} \mathrm{HNO}_{3}$ Contacted - Unsparged & $(2.0 \pm 1.0) \times 10^{-4}$ \\
$4.0 \mathrm{M} \mathrm{HNO}_{3}$ Contacted - Sparged & $(2.0 \pm 0.9) \times 10^{-4}$ \\
\hline Average & $(3.0 \pm 0.9) \times 10^{-4}$ \\
\hline
\end{tabular}

Table 1: Dose constants $\left(d, \mathrm{kGy}^{-1}\right)$ for the degradation of DEHiBA. DEHiBA exhibited pseudofirst order kinetics, so dose constants were calculated from linear fits of plots of the natural log of concentration vs. absorbed dose. Uncertainties are $99 \%$ confidence intervals calculated from the standard error of regression based on 5 injections per absorbed dose for the two non-acid contacted conditions and three injections per absorbed dose for the four acid-contacted experiments. 


\section{Radiation chemistry of the branched-chain monoamide di-ethylhexyl- isobutyramide}

J. Drader, G. Saint-Louis, J.M. Muller, M-C. Charbonnel, P. Guilbaud, L. Berthon CEA Marcoule, Bagnols-sur-Cèze Cedex, F-30207, France

K. Roscioli-Johnson, C. Zarzana, C. Rae, G. Groenewold, B. J. Mincher Idaho National Laboratory, Idaho Falls ID, 83415, USA

$$
\text { S.P. Mezyk }
$$

California State University, Long Beach, Long Beach, CA, 90840, USA

K. McCann, S. G. Boyes, J. Braley

Colorado School of Mines, Golden, CO, 80401, USA

\section{SUPPLEMENTARY INFORMATION}


Table S1: Compounds observed in the organic phase as a function of experimental conditions.

$\mathrm{L}$ stands for DEHiBA.

\begin{tabular}{|c|c|c|c|c|c|c|c|c|}
\hline \multirow[t]{2}{*}{$\mathbf{m} / \mathbf{z}$} & \multirow[t]{2}{*}{ Formula } & \multirow[t]{2}{*}{ Unirrad. } & \multicolumn{2}{|c|}{ Org. only } & \multicolumn{2}{|c|}{$0.1 \mathrm{M} \mathrm{HNO}_{3}$} & \multicolumn{2}{|c|}{$4 \mathrm{M} \mathrm{HNO}_{3}$} \\
\hline & & & Unsparged & Sparged & Unsparged & Sparged & Unsparged & Sparged \\
\hline 198 & {$\left[\mathrm{C}_{12} \mathrm{H}_{22} \mathrm{NO}\right] \mathrm{H}^{+}$} & & & & & & $\mathrm{X}$ & \\
\hline 200.2 & {$\left[\mathrm{C}_{12} \mathrm{H}_{24} \mathrm{NO}\right] \mathrm{H}^{+}$} & & $\mathrm{X}$ & $\mathrm{X}$ & $\mathrm{X}$ & $\mathrm{X}$ & $\mathrm{X}$ & $\mathrm{X}$ \\
\hline 236.1 & & & & & & $\mathrm{X}$ & & \\
\hline 240.2 & {$\left[\mathrm{C}_{16} \mathrm{H}_{33} \mathrm{~N}\right] \mathrm{H}^{+}$} & & $\mathrm{X}$ & & $\mathrm{X}$ & & $\mathrm{X}$ & $\mathrm{X}$ \\
\hline 242.2 & {$\left[\mathrm{C}_{16} \mathrm{H}_{35} \mathrm{~N}\right] \mathrm{H}^{+}$} & $\mathrm{X}$ & $\mathrm{X}$ & $\mathrm{X}$ & $\mathrm{X}$ & $\mathrm{X}$ & $\mathrm{X}$ & $\mathrm{X}$ \\
\hline 254.1 & {$\left[\mathrm{C}_{16} \mathrm{H}_{31} \mathrm{NO}\right] \mathrm{H}^{+}$} & & & & $\mathrm{X}$ & & $\mathrm{X}$ & $\mathrm{X}$ \\
\hline 256.0 & {$\left[\mathrm{C}_{16} \mathrm{H}_{33} \mathrm{NO}\right] \mathrm{H}^{+}$} & & $\mathrm{X}$ & $\mathrm{X}$ & & $\mathrm{X}$ & & \\
\hline 258.2 & {$\left[\mathrm{C}_{16} \mathrm{H}_{35} \mathrm{NO}\right] \mathrm{H}^{+}$} & & & & & $\mathrm{X}$ & & $\mathrm{X}$ \\
\hline 270.3 & & & & $\mathrm{X}$ & & & & \\
\hline 284.3 & & & & & $\mathrm{X}$ & & & \\
\hline 292.1 & & & & & & $\mathrm{X}$ & & $\mathrm{X}$ \\
\hline 296.2 & & & & & $\mathrm{X}$ & & & \\
\hline 298.3 & & & & & $\mathrm{X}$ & & & \\
\hline 310.2 & {$\left[\mathrm{C}_{20} \mathrm{H}_{39} \mathrm{NO}\right] \mathrm{H}^{+}$} & & $\mathrm{X}$ & $\mathrm{X}$ & $\mathrm{X}$ & $\mathrm{X}$ & $\mathrm{X}$ & $\mathrm{X}$ \\
\hline 312.2 & $\mathrm{LH}+$ & $\mathrm{X}$ & $\mathrm{X}$ & $\mathrm{X}$ & $\mathrm{X}$ & $\mathrm{X}$ & $\mathrm{X}$ & $\mathrm{X}$ \\
\hline 326.0 & {$\left[\mathrm{C}_{20} \mathrm{H}_{39} \mathrm{NOO}\right] \mathrm{H}^{+}$} & & $\mathrm{X}$ & $\mathrm{X}$ & $\mathrm{X}$ & $\mathrm{X}$ & & $\mathrm{X}$ \\
\hline 328.0 & {$\left[\mathrm{C}_{20} \mathrm{H}_{40} \mathrm{NOOH}\right] \mathrm{H}^{+}$} & & $\mathrm{X}$ & $\mathrm{X}$ & $\mathrm{X}$ & $\mathrm{X}$ & $\mathrm{X}$ & \\
\hline 334.2 & $\mathrm{LNa}^{+}$ & $\mathrm{X}$ & $\mathrm{X}$ & $\mathrm{X}$ & $\mathrm{X}$ & $\mathrm{X}$ & $\mathrm{X}$ & \\
\hline 340.2 & {$\left[\mathrm{C}_{20} \mathrm{H}_{37} \mathrm{NO}_{3}\right] \mathrm{H}^{+}$} & & $\mathrm{X}$ & & $\mathrm{X}$ & & & \\
\hline 348.2 & & & & & & $\mathrm{X}$ & & \\
\hline 350.0 & $\mathrm{LK}^{+}$ & $\mathrm{X}$ & $\mathrm{X}$ & $\mathrm{X}$ & $\mathrm{X}$ & $\mathrm{X}$ & $\mathrm{X}$ & $\mathrm{X}$ \\
\hline 354.0 & & $\mathrm{X}$ & $\mathrm{X}$ & & & & & \\
\hline 364.2 & & & & & & $\mathrm{X}$ & & \\
\hline 379.2 & & & & & & & $\mathrm{X}$ & \\
\hline 380.1 & & & & & & $\mathrm{X}$ & & \\
\hline 395.3 & & & & & & & & $\mathrm{X}$ \\
\hline 408.4 & {$\left[\mathrm{C}_{28} \mathrm{H}_{57} \mathrm{~N}\right] \mathrm{H}^{+}$} & & $\mathrm{X}$ & & $\mathrm{X}$ & & & \\
\hline 410.5 & {$\left[\mathrm{C}_{28} \mathrm{H}_{59} \mathrm{~N}\right] \mathrm{H}^{+}$} & & $\mathrm{X}$ & & $\mathrm{X}$ & & & \\
\hline 480.5 & {$\left[\mathrm{C}_{32} \mathrm{H}_{65} \mathrm{NO}\right] \mathrm{H}^{+}$} & & $\mathrm{X}$ & $\mathrm{X}$ & $\mathrm{X}$ & & & \\
\hline 533.5 & & & $\mathrm{X}$ & & $\mathrm{X}$ & $\mathrm{X}$ & & \\
\hline 549.5 & {$\left[\mathrm{C}_{36} \mathrm{H}_{72} \mathrm{~N}_{2} \mathrm{O}\right] \mathrm{H}^{+}$} & & $\mathrm{X}$ & & $\mathrm{X}$ & $\mathrm{X}$ & & \\
\hline 551.7 & {$\left[\mathrm{C}_{36} \mathrm{H}_{74} \mathrm{~N}_{2} \mathrm{O}\right] \mathrm{H}^{+}$} & & $\mathrm{X}$ & & $\mathrm{X}$ & & & \\
\hline 603.3 & & & & & & $\mathrm{X}$ & & $\mathrm{X}$ \\
\hline 623.0 & $\mathrm{~L}_{2} \mathrm{H}^{+}$ & $\mathrm{X}$ & $\mathrm{X}$ & $\mathrm{X}$ & & $\mathrm{X}$ & $\mathrm{X}$ & $\mathrm{X}$ \\
\hline 645.5 & $\mathrm{~L}_{2} \mathrm{Na}^{+}$ & $X$ & $\mathrm{X}$ & $\mathrm{X}$ & $\mathrm{X}$ & $\mathrm{X}$ & $\mathrm{X}$ & $\mathrm{X}$ \\
\hline 661.1 & $\mathrm{~L}_{2} \mathrm{~K}^{+}$ & $\mathrm{X}$ & & & $\mathrm{X}$ & $\mathrm{X}$ & $\mathrm{X}$ & $\mathrm{X}$ \\
\hline
\end{tabular}


Table S2: Compounds observed in the aqueous phase as a function of experimental conditions. $\mathrm{L}$ stands for DEHiBA.

\begin{tabular}{|c|c|c|c|c|c|}
\hline \multirow[t]{2}{*}{$\mathbf{m} / \mathbf{z}$} & \multirow[t]{2}{*}{ Formula } & \multicolumn{2}{|c|}{$0.1 \mathrm{M} \mathrm{HNO}_{3}$} & \multicolumn{2}{|c|}{$4 \mathrm{M} \mathrm{HNO}_{3}$} \\
\hline & & Unsparged & Sparged & Unsparged & Sparged \\
\hline 126.2 & {$\left[\mathrm{C}_{8} \mathrm{H}_{15} \mathrm{~N}\right] \mathrm{H}^{+}$} & $X$ & $\mathrm{X}$ & $X$ & $\mathrm{X}$ \\
\hline 130.3 & {$\left[\mathrm{C}_{8} \mathrm{H}_{19} \mathrm{~N}\right] \mathrm{H}^{+}$} & $X$ & $\mathrm{X}$ & $\mathrm{X}$ & $X$ \\
\hline 139.1 & & & & $X$ & \\
\hline 140.2 & & & $X$ & & \\
\hline 142.2 & & $X$ & $\mathrm{X}$ & & $X$ \\
\hline 144.1 & & & $\mathrm{X}$ & & \\
\hline 170.1 & & & & & $X$ \\
\hline 172.2 & & $X$ & & $\mathrm{X}$ & \\
\hline 186.2 & & $\mathrm{X}$ & & & \\
\hline 198.2 & {$\left[\mathrm{C}_{12} \mathrm{H}_{22} \mathrm{NO}\right] \mathrm{H}^{+}$} & $X$ & $\mathrm{X}$ & & $\mathrm{X}$ \\
\hline 200.2 & {$\left[\mathrm{C}_{12} \mathrm{H}_{24} \mathrm{NO}\right] \mathrm{H}^{+}$} & $X$ & & $\mathrm{X}$ & $X$ \\
\hline 202.2 & & & & $\mathrm{X}$ & $X$ \\
\hline 214.2 & & $X$ & $\mathrm{X}$ & $X$ & \\
\hline 234.1 & & & & & $X$ \\
\hline 238.2 & {$\left[\mathrm{C}_{16} \mathrm{H}_{31} \mathrm{~N}\right] \mathrm{H}^{+}$} & & & $\mathrm{X}$ & $X$ \\
\hline 240.2 & {$\left[\mathrm{C}_{16} \mathrm{H}_{33} \mathrm{~N}\right] \mathrm{H}^{+}$} & $X$ & & $\mathrm{X}$ & $X$ \\
\hline 242.2 & {$\left[\mathrm{C}_{16} \mathrm{H}_{35} \mathrm{~N}\right] \mathrm{H}^{+}$} & $X$ & $\mathrm{X}$ & & \\
\hline 254.2 & {$\left[\mathrm{C}_{16} \mathrm{H}_{31} \mathrm{NO}\right] \mathrm{H}^{+}$} & & & & $\mathrm{X}$ \\
\hline 255.3 & & $X$ & & & \\
\hline 256.0 & {$\left[\mathrm{C}_{16} \mathrm{H}_{33} \mathrm{NO}\right] \mathrm{H}^{+}$} & & $\mathrm{X}$ & & \\
\hline 258.2 & {$\left[\mathrm{C}_{16} \mathrm{H}_{35} \mathrm{NO}\right] \mathrm{H}^{+}$} & & & & $X$ \\
\hline 274.2 & & & & & $X$ \\
\hline 310.2 & {$\left[\mathrm{C}_{20} \mathrm{H}_{39} \mathrm{NO}\right] \mathrm{H}^{+}$} & & $\mathrm{X}$ & $\mathrm{X}$ & $X$ \\
\hline 312.2 & $\mathrm{LH}+$ & & $\mathrm{X}$ & $\mathrm{X}$ & $X$ \\
\hline 326.0 & {$\left[\mathrm{C}_{20} \mathrm{H}_{39} \mathrm{NOO} \mathrm{H}^{+}\right.$} & & & $\mathrm{X}$ & $X$ \\
\hline 328.0 & {$\left[\mathrm{C}_{20} \mathrm{H}_{40} \mathrm{NOOH}\right] \mathrm{H}^{+}$} & & & $X$ & \\
\hline 334.2 & $\mathrm{LNa}^{+}$ & & & & \\
\hline 340.2 & {$\left[\mathrm{C}_{20} \mathrm{H}_{37} \mathrm{NO}_{3}\right] \mathrm{H}^{+}$} & & & $X$ & $X$ \\
\hline
\end{tabular}

